\title{
Ranking Port State Control Detention Remarks: Professional Judgement and Spatial Overview
}

\author{
Efe Akyurek ${ }^{*}$, Pelin Bolat ${ }^{2}$ \\ 1 Istanbul Technical University; akyureke@itu.edu.tr \\ 2 Istanbul Technical University; yilmazp@itu.edu.tr \\ * Correspondence: akyureke@itu.edu.tr; Tel.: (+31 655 606326)
}

\begin{abstract}
Merchant marine fleet is under inspections by several parties to ensure maritime regulation compliance. One major effect on implementation regulations of International Maritime Organization is indeed Port State Control. This article aims to analyze Paris Memoranda of Understanding vessel detention remarks for EU15 countries (except Luxemburg and Austria) through an approach based on Analytical Hierarchy Process and demonstrate results on Geographic Information System to guide industry on detainable Port State Control remarks and country risk profile of vessel detention. While Analytical Hierarchy Process assists to indicate the ranking of maritime regulations from the perspective of the Port State Control, GIS demonstrate the regional dispersion amongst EU15. Consequently, the results of the study assist Port State Officers, ship crew, owners and managers presenting the facts of inspection and able to improve themselves. The spatial analysis expected to guide ship owners and managers to focus their vessel's deficiencies to prevent sub-standardization.
\end{abstract}

Keywords: Port State Control;AHP; Paris MOU; GIS; Maritime Regulations

\section{Introduction}

fleet. During this enhancement, the control mechanism for compliance of the international regulations comes one step further. The history clearly demonstrates many examples of great disasters which sub-standards vessels cause. Ultimately, the Port State Control for merchant vessels is developed as a control mechanism to fight against the sub-standard vessels to prevent disasters and save human life as well.

The idea of Port State jurisdiction has emerged as a result of the Third United Nations Conference on the Law of the Sea. Amended to 1982 United Nations Convention on the Law of the Sea, the port state control appeared as an innovative tool to fight against marine pollution caused by ships. The need for port state control appears with a lack of international standards in the shipping industry. While International Maritime Organization regulates the industry, dynamics of shipping constantly tries to resist. Ultimately, the Memoranda of Understanding on Port State Control developed by cooperative regional agreements and does a significant effect on international maritime regulations and standards including fight against pollution [1].

The success of Port State Control to fight against sub-standardization for maritime industry depends on share of information and it is not convenient to inspect a ship at each port. Besides regional formations would come one step further since states are bonded together [2]. Therefore, Memoranda of Understanding for states was inevitable and currently ten (10) individual and geographically tied together MOUs cover majority of world coastal areas.

The basic argument is based on success of Port State Control conducted under MOU's and there are several studies on same approach of analyzing Port State Control Report observations. Researches show that $63 \%$ of vessels exhibit fewer remarks on following Port State Control inspections. This fact 
is an important sign that enforcement of international regulations to prevent pollution and accidents is more successful on following inspections [3]. This article aims to rank Port State Control remarks which cause vessel detention to reveal with an analysis for shipowners and/or managers to prevent their vessels to become substandard.

The Memorandum of Understanding officially set right after the massive oil spill of the VLCC 'Amoco Cadiz' on March 1978. However, the current formation signed in January 1982 by fourteen European countries at Paris, France. Currently, it is not required to be a European Union country to become a member authority for Paris MOU.

The Paris MOU aims to ensure safety of life at sea, prevention of pollution by ships, and living and working conditions on the board ships. Within these goals, the organization have developed several strategies to eliminate sub-standard vessel from member Authority coastal waters. The Paris MOU has currently twenty-seven (27) member states, as two out of twenty-seven members are not European Union member country (Table 1).

\begin{tabular}{|c|c|c|c|c|}
\hline Belgium & Bulgaria & Canada ${ }^{(1)}$ & Croatia & Cyprus \\
\hline Germany & Denmark & Estonia & Finland & France \\
\hline Greece & Iceland & Ireland & Italy & Latvia \\
\hline Lithuania & Malta & the Netherlands & Norway & Poland \\
\hline Portugal & Romania & $\begin{array}{l}\text { the Russian } \\
\text { Federation }^{(1)}(2)\end{array}$ & Slovenia & Spain \\
\hline Sweden & $\begin{array}{l}\text { the United } \\
\text { Kingdom }\end{array}$ & & & \\
\hline \multicolumn{5}{|c|}{$\begin{array}{l}\text { - Note (1): Canada and Russian Federation are not member states of European Union } \\
\text { - Note (2): Russian Federation Black Sea ports are in the scope of Black Sea Memoranda } \\
\text { of Understanding }\end{array}$} \\
\hline
\end{tabular}

Table 1. Country List of the Member Maritime Authorities of Paris MOU.

Paris MOU administration have developed various guidelines to assist related parties (including Port State Control Officers) on proper ship inspection. According to the procedures and the guidelines, a Port State Control Officer shall act under professional attitude during the inspection and determine vessel detention, if necessary, under professional judgement.

According to EMSA (European Maritime Safety Agency), over 200,000 ships are trading in European waters at any time [4]. Subject ships for inspection are too wide to take control and it is not feasible and practicable that inspecting $25 \%$ of the ships arriving at MoU ports, as well. Thus, a New Inspection Regime (NIR) for Port State Control has been adopted on 1 January 2011. This system assists the Paris MOU to identify the good ship-owner [5]. Not only the Inspection Regime, but the Concentrated Inspection Campaigns (CIC) also targets to increase standards for vessels and raise awareness. CIC results are also subject to several researches to identify sub-standard vessels [6].

In this article, the literature review section analyzes several scholarly studies that analyze Port State Control related deficiencies based on Port State Control Report data. Since the scope of the research is limited for Paris MOU (Memorandum of Understanding) database, the data collection section briefly explains the data selection from Paris MOU website and methodology section explains how AHP (Analytical Hierarchy Process) approach is integrated with the data and ARCGIS software. The Port State Control Officer carries out an inspection and according to the inspection procedures, each 
decision step (inspection type, deficiencies noted and detention) requires professional judgement. Finally, the discussion and conclusion section explain the novelty of this research as its contribution to the existing literature together with pointing possible future researches.

\section{Background}

In the literature, the use and analysis of Geographic Information System (GIS) tool is limited to analyzing Port State Control actions. Studies on GIS have much more focused on Automatic Identification System (AIS)- navigation data and their analyzes. For example, a study has been done based on data collection of ships Automatic Identification System (AIS) in Indonesia and analysis by use of AHP and GIS. The article intersected the research by assuming that the foreign flagged vessels were probably inspected by Port State Control to determine the hazard score of the vessels [7]. The original aspect of AHP ranking approach, uses detainable deficiency remarks of Port State Control reports to demonstrate which state focus on what specific deficiency in general to encourage ship owners/ managers to rectify their possible remarks in extreme caution.

The literature review more focused on articles that use GIS, Port State Control deficiency codes and categories. The methodology conducted in these articles related to Port State Control Inspection data can be exemplified as; probability analysis [8], Bayesian Network Model [9], Possion \& negative binomial model [10], bivariate Probit models [11] and, binary logic regression [12].

A successful safety analysis of ships has been carried out with using a Port State Control Inspection data with binary logic regression and concludes that, about $4.9 \%$ of PSC eligible vessels have been targeted accordingly, but they had an accident within six months after the port state control and $4.7 \%$ of ships had an accident onboard, yet was not inspected after the accident occurred [12]. It is a remarkable question that why $4.7 \%$ of the ships did not inspect by any Port State Control authority. Not only the coverage of Port States affects the inspection, but the economics plays a crucial role too. The measured inspection costs of a port state control are USD 747 per inspection [13] and the majority of world economics is not strong enough to bear this cost.

The probability analysis with 183,819 inspections carried out by categorizing the inspection codes of all MOUs, vessel types and accidents. Findings indicate that more focused inspections on the ISM code, machinery and equipment and ship and cargo operations decreases the possibility of accidents [8]. Another accident related analysis set by Bayesian Network Model on Finland \& Baltic Sea accident reports. The variables for Bayesian Network Model are Port State Control deficiency categories, vessel types, vessel flag and age. The findings indicate that an inspected ship with no accidents is more likely to be a tanker or other ship and less likely a passenger ship [9].

The change of vessel flag and port state control inspection relation analyzed by a bivariate Probit model from 7500 ship inspections. The two major finding indicates that relatively vessels in bad condition are tend to change flag or classification society on following inspection. Besides, any vessel changed flag or classification society before is tend to change flag or classification society [11]. Another study carried out analyzing number of deficiencies, ISM Code compliance, ship age, flag and ship type reveals that deficiency numbers are related to vessel age. Relatively positive and negative changes in deficiency numbers occurs on Ro-Ro passenger, chemical and oil tankers, bulk carriers and general cargo carriers [10].

Figure 1. demonstrates the diversification of articles and dissertations related to Port State Control by the content. The earlier studies are more related to legal aspects of Port State Control on United Nations Law on Sea (UNCLOS) aspect. Later on, Scholarly articles commonly use the Port State Control inspection reports as an output to evaluate the industry on safety \& security, pollution and, economic aspects. 


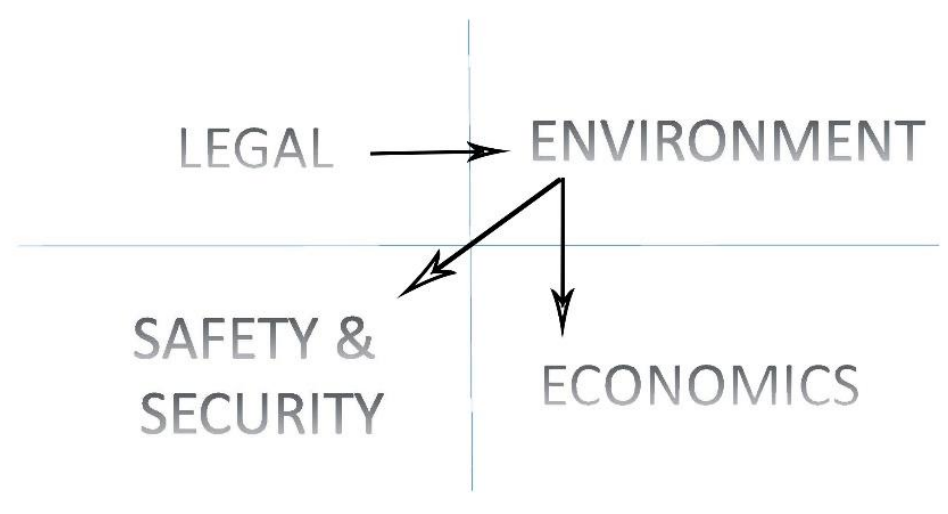

Figure 1. Diversification of articles and dissertations related to Port State Control

While early studies are more related to legal and environmental aspects, recent studies use Port State Control Inspection data for safety \& security and economic impact of Port State Control. This study aims to integrate Analytic Hierarchy Process (AHP) ranking approach with the PSC inspection reports foreach international regulation to handle the and percentile of detentions and demonstrated the hierarchy of the detention criteria on Geographic Information System (GIS).

The AHP method-based articles, on the other hand, are available for analyzing Port State Control structure and actions. A three-stage methodology article aimed to restructure the PSC Authority of Taiwan by using AHP on the second stage. The study proposes that the PSC Authority shall be restructured under the Ministry of Transportation and Communications [14]. Not only the Port State Control but the maritime conventions also discussed under the scope of AHP. The AHP indicates that Maritime Labor Convention compliance is fundamental on the financial perspectives, such as employment agreements and crew salary payment [15].

The Port State Control Officer carries out an inspection and according to the inspection procedures, each decision step (inspection type, deficiencies noted and detention) requires professional judgement. In another perspective, the Port State Control Officer is the key person in operation who works in the field. The Officer is both initial and final determinant for the detention. This study can also be read as the continuation of Port State Control Officer effect on the industry. The Control Officer background is determined by guidelines. The main point is, the PSC Officer background have an effect on vessel detentions. For an instance, engineering background inspectors are more tend to detain the vessels compared to nautical background [16]. It is a fact that some detention items are open for dispute. Besides, engineer background inspectors are more careful about auxiliary machinery caused deficiencies [17]. Aside from the inspector's background, this article focuses on the professional judgement of the Port State Control Officers.

The port state control officer attends onboard and upon completion of the inspection delivers a report that issued under several professional judgements. According to Paris MOU Procedures on Guidance on Detention and Action Taken, the detention decision depends on professional judgement of attending Port State Control Officer indicated as below:

When exercising professional judgement as to whether or not a ship should be detained the PSCO will apply the following criteria:

.1 Timing: ships which are unsafe to proceed to sea will be detained upon the first inspection irrespective of the time the ship will stay in port; 
.2 Criterion: the ship will be detained if the deficiencies on a ship are sufficiently serious to merit a PSCO returning to the ship to be satisfied that they have been rectified before the ship sails.

On this sense, all Port State Control detention remarks are accepted as a professional judgement which is essential for ranking based Analytic Hierarchy Process. The variety of detainable remarks shall indicate the root cause of detention. The domestic procedures for Port State control includes the legal remarks for the detention [18]. Below aspects of literature review and existing assumptions takes a role on below methodology and data selection.

\section{Methodology and Data Selection}

The principal Maritime Regulations have settled by SOLAS (Safety of Life at Sea) Convention after Titanic accident. The SOLAS Convention and related regulations have been expanded with lessons learned and pro-active legislation and due to this enhancement, several chapters become an individual Code. This study will divide regulations as follows:

- SOLAS Convention (Safety of Life at Sea),

- LL (International Convention on Load Lines),

- DG (Dangerous Goods - including International Bulk Chemical Code (IBC Code), The International Code of the Construction and Equipment of Ships Carrying Liquefied Gases in Bulk (IGC Code) and the (IMDG Code) International Maritime Dangerous Goods Code),

- $\quad$ LSA-Code International Life-saving appliance Code (MSC.48(66))

- FSS Code (Fire Safety Systems Code),

- MLC (Maritime Labor Convention, 2006 - including ILO Conventions),

- MARPOL (International Convention for the Prevention of Pollution from Ships, 1973 as modified by the Protocol of 1978), and

- ISM Code (International Safety Management).

The Paris MOU list of deficiency codes are listed on public website. The deficiency codes explain each deficiency explicitly with an explanation by its nature. The majority of the eighteen (18) general defective items are divided by their sub-items. The Port State Control deficiencies which cause a detention has been collected from the public website and collected by its general defective items. The main point is, number 01 - Certificates and Documentation and 99 - Other deficiencies are omitted. The certificates and documentation items are complicated by including various sub-items related to multiple major regulation described below. The similar issue is also same for other deficiency items. 


\section{- Port State Control Reports by country}

- Sorting detained vessels

- Create a database by detainable deficiency codes

Step 2

-Determination of Relative Importance of Detainable Deficiencies by Country

-Demonstration of relative importance of International Maritime Regulations on vessel

Step 3 detentions

Step 4

-Ranking List for International Maritime Regulations

Output

-ArcGIS demonstration of AHP results comparing with percentage of detainable remarks

Figure 2. Proposed method of methodology for ranking list of International Maritime Regulations by Analytical Hierarchy Process (AHP).

The methodology is based on 4 steps as described on Figure 2. The first 3 steps are essential to demonstrate AHP and the hierarchy model and ranking table to be presented on following paragraphs. The output achievement of AHP is ranking list for International Regulations and finally the results demonstrated by ArcGIS together with percentage of detainable remark for each regulation by country. By this means the methodology aims guide policy makers, Port State Control Officers, ship managers/owners on detainable Port State Control remarks and country risk profile on ship detention considering International Regulations.

Table 2. indicates the deficiency codes (as factors) determined by Paris MOU under principal International Maritime Regulations.

\begin{tabular}{|c|c|c|c|c|c|c|c|c|}
\hline \multirow{2}{*}{ FACTORS } & \multicolumn{8}{|c|}{ CRITERIA } \\
\hline & SOLAS & LL & DG & LSA & FSS & MLC & MARPOL & ISM \\
\hline 01 - Certificates \& Documentation & $x$ & $x$ & $x$ & $x$ & $x$ & $x$ & $x$ & $x$ \\
\hline 02 - Structural condition & $x$ & & & & & & & \\
\hline 03 - Water/Weathertight condition & & $x$ & & & & & & \\
\hline 04 - Emergency Systems & $x$ & & & & & & & \\
\hline 05 - Radio communication & $x$ & & & & & & & \\
\hline $\begin{array}{l}06 \text { - Cargo operations including } \\
\text { equipment }\end{array}$ & & & $x$ & & & & & \\
\hline 07 - Fire safety & & & & & $x$ & & & \\
\hline 08 - Alarms & $\mathrm{X}$ & & & & & & & \\
\hline 09 - Working and Living Conditions & & & & & & $x$ & & \\
\hline 10 - Safety of Navigation & $x$ & & & & & & & \\
\hline 11 - Life saving appliances & & & & $x$ & & & & \\
\hline 12 - Dangerous Goods & & & $x$ & & & & & \\
\hline 13 - Propulsion and auxiliary & $x$ & & & & & & & \\
\hline
\end{tabular}




\begin{tabular}{|l|l|l|l|l|l|l|l|l|}
\hline machinery & & & & & & & & \\
\hline $14-$ Pollution Prevention & & & & & & & $x$ & \\
\hline $15-$ ISM & & & & & & & & $x$ \\
\hline $16-$ ISPS & & & & & & & & \\
\hline $18-$ MLC, 2006 & & & & & & $x$ & & \\
\hline $99-$ Other & $\mathrm{X}$ & $\mathrm{X}$ & $\mathrm{X}$ & $\mathrm{X}$ & $\mathrm{x}$ & $\mathrm{x}$ & $\mathrm{X}$ & $\mathrm{X}$ \\
\hline
\end{tabular}

Table 2. Relevance matrix for Paris MOU deficiency codes with International Maritime regulations

During data collection, all inspection remarks have been collected from 01 January 2013 to 01 January 2019 with all detention remarks while only detainable remarks has been selected for further process. The further analysis decided to be carried out by omitting 01,16 and 99 deficiency codes. The Certificates \& Documentation remark sometimes is very complicated and even one remark may combine several principal Criteria. Related to this, 99 - Other remarks are not very well explained on website and only way to get in-depth information is to check the original report for subject ship by Port State Control Officer/s. The reason deficiency code 16 omitted is, no ship detained by this remark in the historical records. Therefore, a database has been created to sum all detainable remarks related to international maritime regulations.

After all detainable remarks have been sorted, a percentage values on SOLAS, Load Line, Dangerous Goods, Fire Safety Systems, Life Saving Appliances, Marpol, Maritime Labour Convention and International Safety Management codes related deficiencies are calculated to infer a general idea on overall ship detention for International Maritime Regulations aspect.

\begin{tabular}{|l|l|l|l|l|l|l|l|l|}
\hline \multirow{2}{*}{ EU 15 Countries } & \multicolumn{7}{l}{ International Maritime Regulations } \\
\cline { 2 - 10 } & SOLAS & LL & DG & FSS & LSA & MARPOL & MLC & ISM \\
\hline BELGIUM & 7,13 & 16,46 & 10,45 & 6,66 & 7,01 & 4,62 & 6,62 & 5,29 \\
\hline DENMARK & 0,23 & 0 & 0 & 0,5 & 0,27 & 0,36 & 0,9 & 0,21 \\
\hline FINLAND & 0,11 & 0 & 0 & 0 & 0,09 & 0 & 0 & 0,07 \\
\hline FRANCE & 4,2 & 3,58 & 5,97 & 5,05 & 4,26 & 4,97 & 4,58 & 2,95 \\
\hline GERMANY & 6,22 & 9,66 & 10,45 & 7,93 & 3,11 & 8,53 & 5,8 & 6,32 \\
\hline GREECE & 27,82 & 26,83 & 5,97 & 17,01 & 26,97 & 13,32 & 21,98 & 17,1 \\
\hline IRELAND & 2,16 & 1,79 & 0 & 5,6 & 5,06 & 1,6 & 0,82 & 4,19 \\
\hline ITALY & 23,44 & 13,77 & 32,84 & 33,62 & 25,38 & 28,77 & 20,83 & 27,27 \\
\hline NETHERLANDS & 4,66 & 12,52 & 11,94 & 6,21 & 4,88 & 12,97 & 2,61 & 5,84 \\
\hline PORTUGAL & 2,55 & 1,61 & 0 & 1,56 & 2,22 & 1,42 & 2,12 & 2,75 \\
\hline SPAIN & 13,05 & 5,9 & 14,93 & 8,23 & 9,85 & 19,72 & 20,42 & 14,08 \\
\hline SWEDEN & 0,6 & 0,72 & 0 & 0,5 & 1,24 & 0,36 & 1,06 & 0,76 \\
\hline UNITED KINGDOM & 7,84 & 7,16 & 7,46 & 7,12 & 9,67 & 3,37 & 12,25 & 13,19 \\
\hline TOTAL & 100 & 100 & 100 & 100 & 100 & 100 & 100 & 100 \\
\hline
\end{tabular}

Table 3. Percentage values for each maritime regulation by EU15 countries (all values are in percentage). 
Table 3 indicates the percentage values for each regulation. According to the table, Greece and Italy overall detainable remark percentage are higher than other member countries. The table also reveals that Finland have no vessel detained for regulations Load Line, Dangerous Goods, FSS Code and MARPOL. It is another fact that the vessel traffic in Baltic Seas is not as high as Mediterranean. Thus, percentage values many create a confusion that some international regulations may not being implemented.

After demonstrating the percentage distribution of International Maritime Regulations by country, the AHP model for this article designed to be a linear network described by Saaty [19] to reach the goal of defining the importance of international maritime regulations for each country aspect. There are various multi-disciplinary examples that applies AHP models for Ship registry selection decision [20], decision making in transportation modes [21], and energy research using GIS/AHP approach [22]. The AHP methodology is also suitable to be combined with TOPSIS, VIKOR, PROMETHEE, DEMATEL, etc.

\section{Deficiency codes related to International Maritime Regulations}
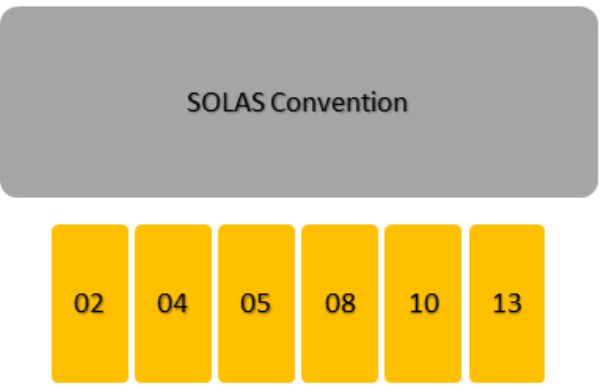
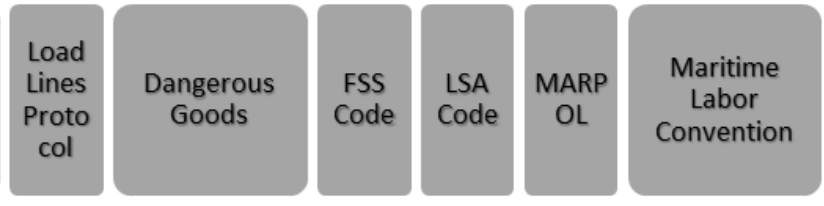

ISM

Code
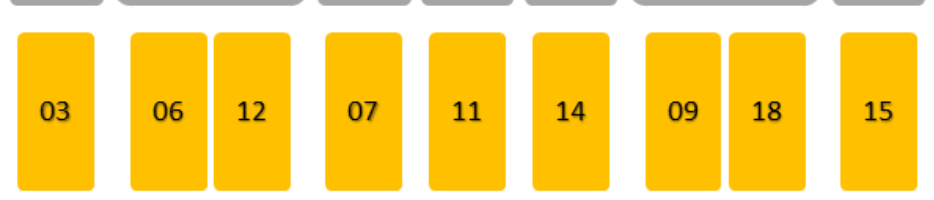

Figure 3. Hierarchical structure of deficiency codes related to International Maritime Regulation

Figure 3 reveals that the majority of the deficiency codes are related to SOLAS Convention means that majority of states are tended to detain the vessels related to SOLAS deficiencies. However, percentage distribution of maritime regulations indicate that each country has a different characteristic on vessel inspection.

The total Port State Control remarks have been evaluated under on a scale of below comparison matrix from 0 to 9 for each country.

\begin{tabular}{|l|l|}
\hline Intensity of Importance & Verbal judgment of preference \\
\hline 0 & No Importance \\
\hline 1 & Very low importance \\
\hline 3 & Low importance \\
\hline 5 & Medium importance \\
\hline 7 & Strong importance \\
\hline 9 & Very strong importance \\
\hline $2,4,6,8$ & $\begin{array}{l}\text { Intermediate values between adjacent } \\
\text { scale values }\end{array}$ \\
\hline
\end{tabular}

Table 4. Relative importance table of AHP analysis [23]. 
The consistency ratio (CR) as a measure inconsistency of each individual state found consistent. The consistency test formula is mentioned in formula 1:

\section{$\mathrm{CR}=\mathrm{CI} / \mathrm{RI}$}

The consistency ratio is important since CR $<0.1$ - the comparison has a consistency. The AHP results have been calculated for each country by considering the consistency ratio is below 0.1 .

\section{Analysis, Results and Discussion}

The AHP has been carried out by summing and categorized all detainable remarks for selected countries. For example, during 01 January 2013 to 01 January 2019, there were 805 detainable remarks occurred in Belgium.

\begin{tabular}{|c|l|l|l|l|l|l|l|l|}
\hline \multicolumn{2}{|l|}{ BELGIUM } \\
\hline SOLAS & LOADLINE & DG & FSS & MLC & LSA & MARPOL & ISM & TOTAL \\
\hline 311 & 92 & 7 & 132 & 81 & 79 & 26 & 77 & 805 \\
\hline
\end{tabular}

Table 5. Total detainable items for Belgium

AHP has been done considering the detention remarks as a result of a professional judgement (decision has been made by Port State Control Officer on detention). The remarks indicate that depends on the inspection, the related remark brings a detention. For an example, a reefer type vessel has been detained by Belgium Port State Control on 02 August 2013, by 07115 - Fire Dampers are not as required. However, another oil/chemical tanker did not detain on 16 November 2016 by same remark at same country. This difference considered as a professional judgement on same remark under different conditions. Even though the objectivity for inspection is essence, the professional judgement may questionable [23].

\begin{tabular}{|l|l|l|l|l|l|l|l|l|}
\hline & SOLAS & LL & IMDG & FSS & MLC & LSA & MARPOL & ISM \\
\hline SOLAS & 1,000 & 3,000 & 9,000 & 2,000 & 5,000 & 5,000 & 7,000 & 4,000 \\
\hline LL & 0,333 & 1,000 & 7,000 & 0,500 & 2,000 & 2,000 & 4,000 & 2,000 \\
\hline IMDG & 0,111 & 0,143 & 1,000 & 0,125 & 0,125 & 0,125 & 0,143 & 0,125 \\
\hline FSS & 0,500 & 2,000 & 8,000 & 1,000 & 3,000 & 2,000 & 6,000 & 3,000 \\
\hline MLC & 0,200 & 0,500 & 8,000 & 0,333 & 1,000 & 1,000 & 5,000 & 1,000 \\
\hline LSA & 0,200 & 0,500 & 8,000 & 0,500 & 1,000 & 1,000 & 5,000 & 1,000 \\
\hline MARPOL & 0,143 & 0,250 & 6,993 & 0,167 & 0,200 & 0,200 & 1,000 & 0,250 \\
\hline ISM & 0,250 & 0,500 & 8,000 & 0,333 & 1,000 & 1,000 & 4,000 & 1,000 \\
\hline
\end{tabular}

Table 6. Analytic Hierarchy Process on detention items at Belgium

Table 6 points the AHP on detainable items by regulations. The matrix is set considering the Analytical Hierarchy Process table by Saaty [23] under an inductive approach. Relatively, the most important item for detention is SOLAS related deficiencies and the importance of FSS is indeed lower than the SOLAS. 
AHP results for EU 15 countries are indicated with consistency ratio.

\begin{tabular}{|l|l|l|l|l|l|l|l|l|l|}
\hline \multirow{2}{*}{ COUNTRIES } & \multicolumn{7}{|l|}{ MAJOR MARITIME REGULATIONS } & \multirow{2}{*}{ CR } \\
\cline { 2 - 10 } & SOLAS & LL & DG & FSS & MLC & LSA & MARPOL & ISM & \\
\hline BELGIUM & $32,9 \%$ & $14,0 \%$ & $1,0 \%$ & $20,0 \%$ & $10,0 \%$ & $10,0 \%$ & $3,0 \%$ & $9,0 \%$ & 0,065 \\
\hline DENMARK & $24,0 \%$ & $2,0 \%$ & $2,0 \%$ & $21,0 \%$ & $29,0 \%$ & $9,0 \%$ & $5,0 \%$ & $8,0 \%$ & 0.024 \\
\hline FINLAND & $47,2 \%$ & $23,2 \%$ & $4,9 \%$ & $4,9 \%$ & $4,9 \%$ & $4,9 \%$ & $4,9 \%$ & $4,9 \%$ & 0,078 \\
\hline FRANCE & $34,0 \%$ & $4,0 \%$ & $2,0 \%$ & $24,0 \%$ & $12,0 \%$ & $10,0 \%$ & $5,0 \%$ & $9,0 \%$ & 0,042 \\
\hline GERMANY & $38,5 \%$ & $5,6 \%$ & $2,1 \%$ & $22,4 \%$ & $8,5 \%$ & $3,6 \%$ & $5,3 \%$ & $14,0 \%$ & 0,060 \\
\hline GREECE & $38,0 \%$ & $5,6 \%$ & $1,7 \%$ & $15,4 \%$ & $10,2 \%$ & $15,4 \%$ & $3,4 \%$ & $10,2 \%$ & 0,066 \\
\hline IRELAND & $25,7 \%$ & $4,2 \%$ & $2,0 \%$ & $31,2 \%$ & $4,5 \%$ & $13,9 \%$ & $3,8 \%$ & $14,7 \%$ & 0,051 \\
\hline ITALY & $38,8 \%$ & $2,2 \%$ & $2,8 \%$ & $23,5 \%$ & $7,5 \%$ & $8,3 \%$ & $4,9 \%$ & $12,0 \%$ & 0,090 \\
\hline NETHERLANDS & $39,8 \%$ & $7,3 \%$ & $2,0 \%$ & $21,8 \%$ & $3,3 \%$ & $5,4 \%$ & $7,6 \%$ & $12,8 \%$ & 0,054 \\
\hline PORTUGAL & $38,4 \%$ & $4,0 \%$ & $2,0 \%$ & $13,9 \%$ & $9,8 \%$ & $8,6 \%$ & $3,7 \%$ & $19,6 \%$ & 0,068 \\
\hline SPAIN & $37,4 \%$ & $3,3 \%$ & $2,0 \%$ & $9,8 \%$ & $20,4 \%$ & $6,5 \%$ & $6,3 \%$ & $14,3 \%$ & 0,040 \\
\hline SWEDEN & $37,3 \%$ & $5,5 \%$ & $2,0 \%$ & $11,1 \%$ & $13,6 \%$ & $14,8 \%$ & $3,4 \%$ & $12,3 \%$ & 0,050 \\
\hline UK & $34,8 \%$ & $5,4 \%$ & $1,7 \%$ & $11,2 \%$ & $13,6 \%$ & $8,1 \%$ & $3,2 \%$ & $22,0 \%$ & 0,074 \\
\hline
\end{tabular}

Table 7. Result of AHP for EU15 countries of major Maritime regulations

Table 6. concludes that majority of countries focus on SOLAS regulations as expected. However, the analysis indicates that Ireland more focused on Fire Safety Systems than SOLAS. Denmark, on the other hand, more focused on MLC than all other regulations. Further priority has been given for FSS code in general and followed by ISM Code. It may be explainable that all regulations have not been in force on same times. For instance, Maritime Labor Convention came in force on 20 August 2013 but there were several regulations by International Labor Organization to regulate crew working and living conditions on ships and these regulations also covered under Maritime Labor Convention.

\begin{tabular}{|l|l|l|l|l|l|l|l|l|}
\hline SOLAS & LL & IMDG & FSS & MLC & LSA & MARPOL & ISM & TOTAL \\
\hline $33,7 \%$ & $5,6 \%$ & $2,0 \%$ & $20,6 \%$ & $11,2 \%$ & $9,0 \%$ & $4,4 \%$ & $13,5 \%$ & $100 \%$ \\
\hline
\end{tabular}

Table 8. The comparison of International Maritime Regulations by detention results.

According to table 7. the SOLAS Convention related deficiencies are prevailing for Paris MOU member EU15 states. Second important convention is Fire Safety Systems. Actually Fire Safety Systems also is a sub chapter for SOLAS Convention, but it is decided to divide an another Code to bring this chapter more user-friendly [24]. The third convention is ISM Code and the code brought to the industry on 1995. The aim of the ISM Code is to regulate the operation safety for both maritime companies and ships [25]. The MLC (formerly ILO Regulations) aims to integrate former ILO regulations to maintain eligible working and living environment for seafarers. 

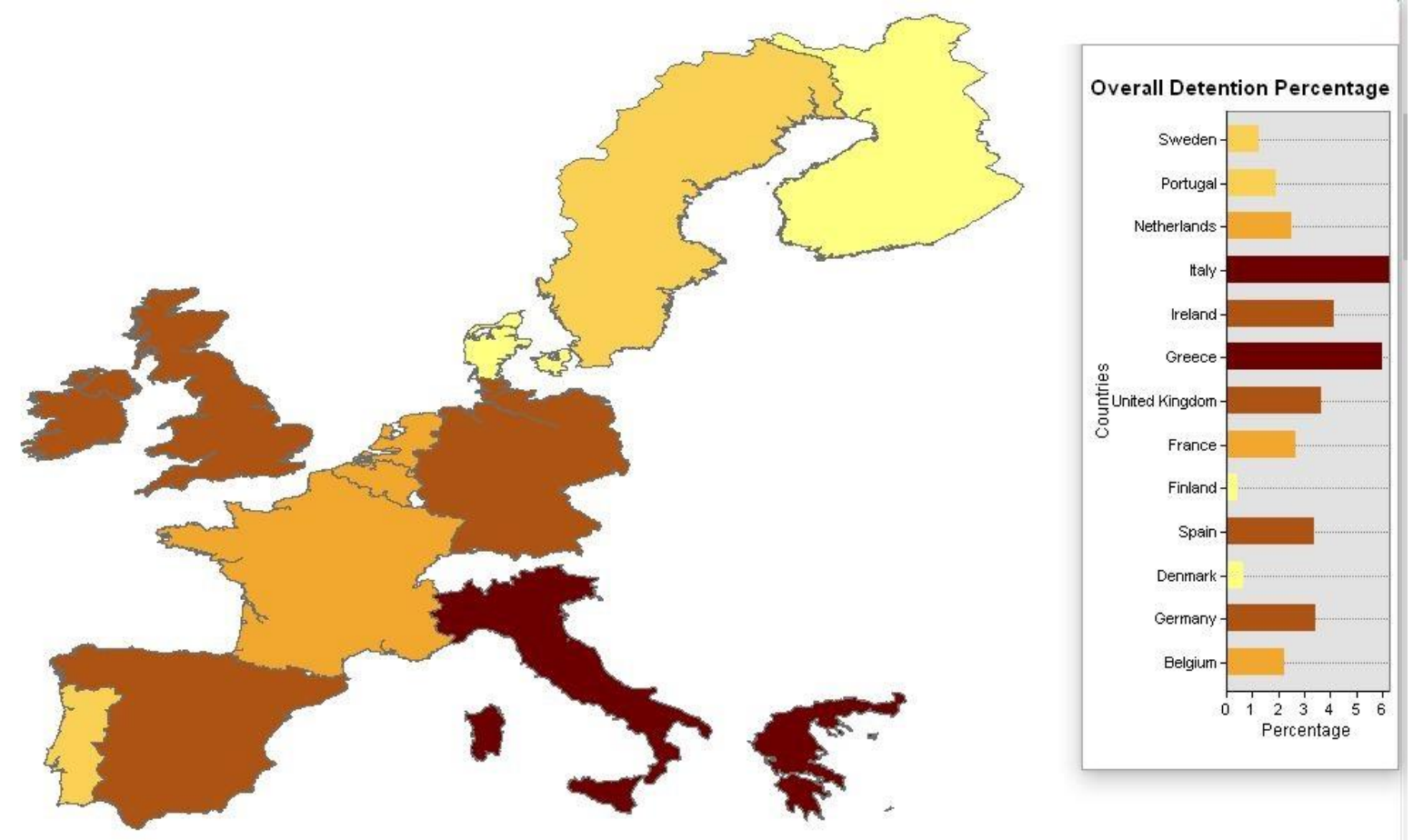

Figure 4. Overall detention percentage for EU15.

The detention percentage is calculated by taking account of all inspection by dividing total detention on the subject state. The figure 3. shows that the detention rate for Paris MOU is higher for the Mediterranean than the other areas. The maximum rate is at Italy with $\% 6$ and the minimum detention rate at Finland. Majority of the Baltic Sea countries detention rate is below the EU15 average rate. The detention rates of France, Belgium and the Netherlands are similar. Considering the traffic density in the Netherlands, Belgium, and Germany, the detention rate is the average rate for the EU15. Besides, the rate for the detention is similar at Spain, Germany, Ireland, and the United Kingdom. 


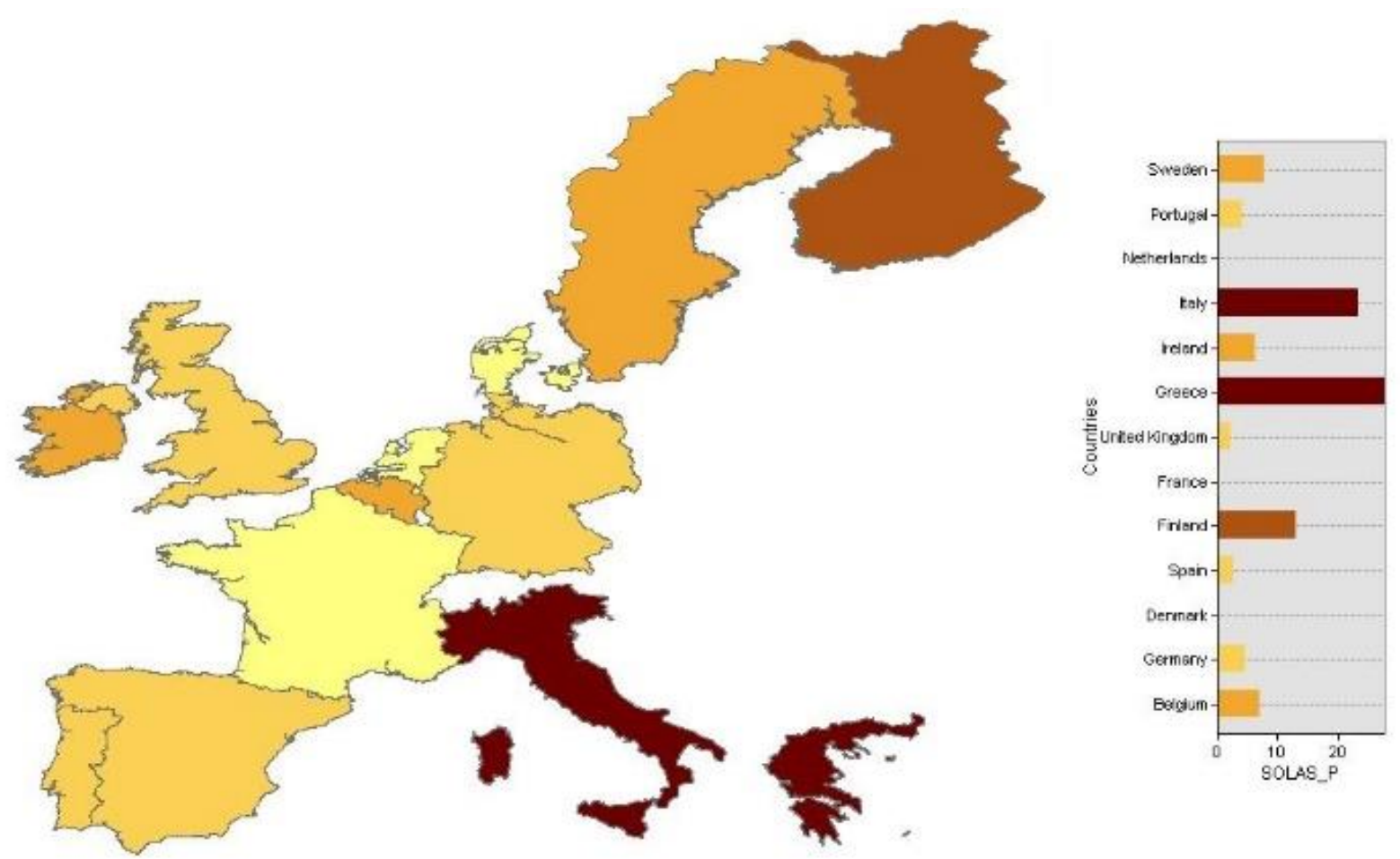

Figure 5. Detainable remarks percentage for SOLAS Convention for EU15 countries.
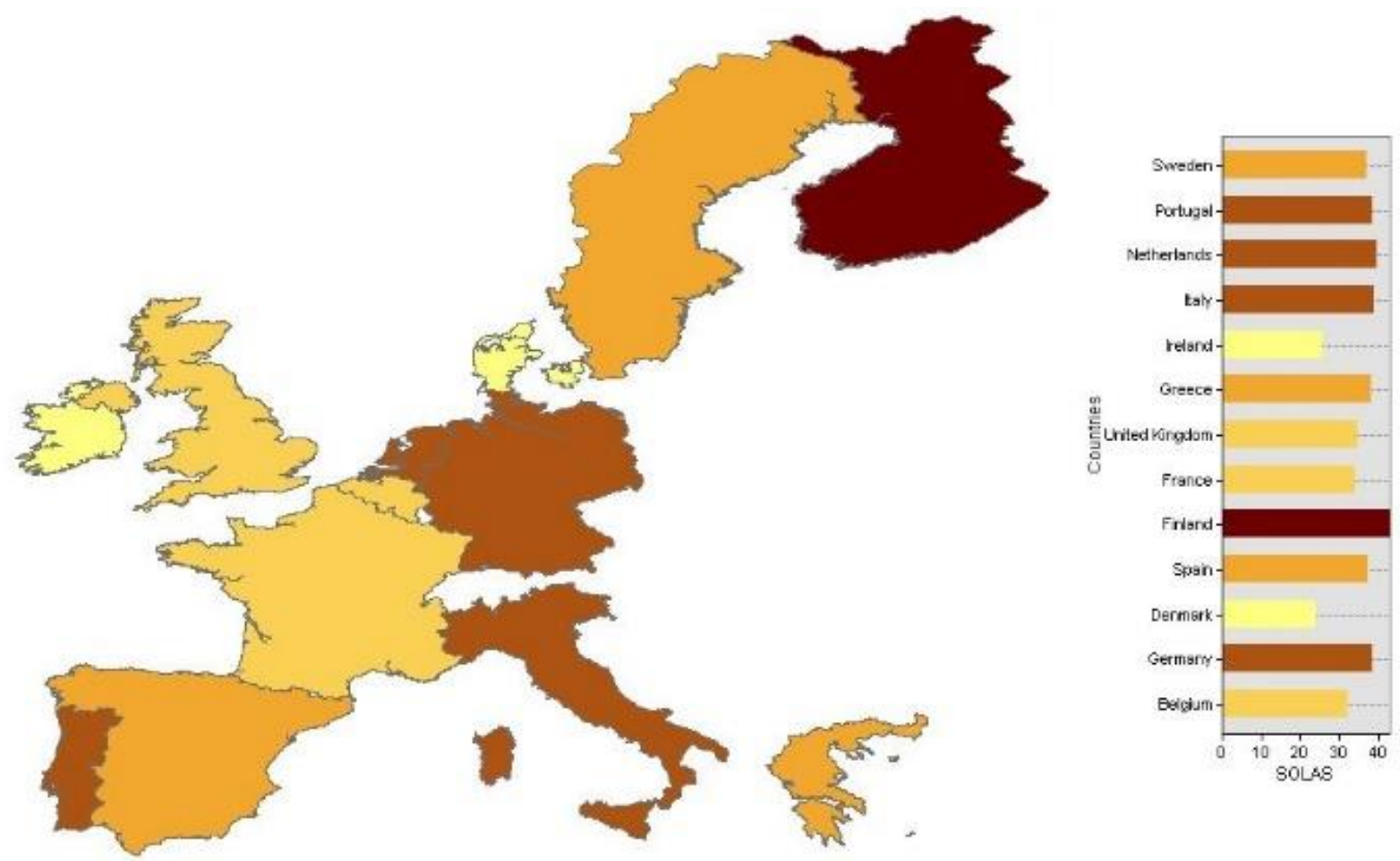

Figure 6. Weighting of SOLAS Convention deficiencies.

SOLAS Convention contains the essential regulations for maritime industry. While figure 4 points the percentage for SOLAS related detentions on countries, figure 6 indicates each country characteristic on SOLAS related detention. This two-step GIS demonstration significate that even 
though a country does not detain as a result of large number on SOLAS related deficiency, not mean that they have facilitated approach on SOLAS deficiencies. The high weight on SOLAS regulations is an expected result for AHP. Besides, the number of regulations and detainable deficiencies have correlation. The highest weighting of SOLAS Convention is Finland, also the overall detention percentage. The highest weighting for the convention is given by Denmark by $24,0 \%$. The convention has similar weighting for Portugal, Italy, Germany and the Netherlands.
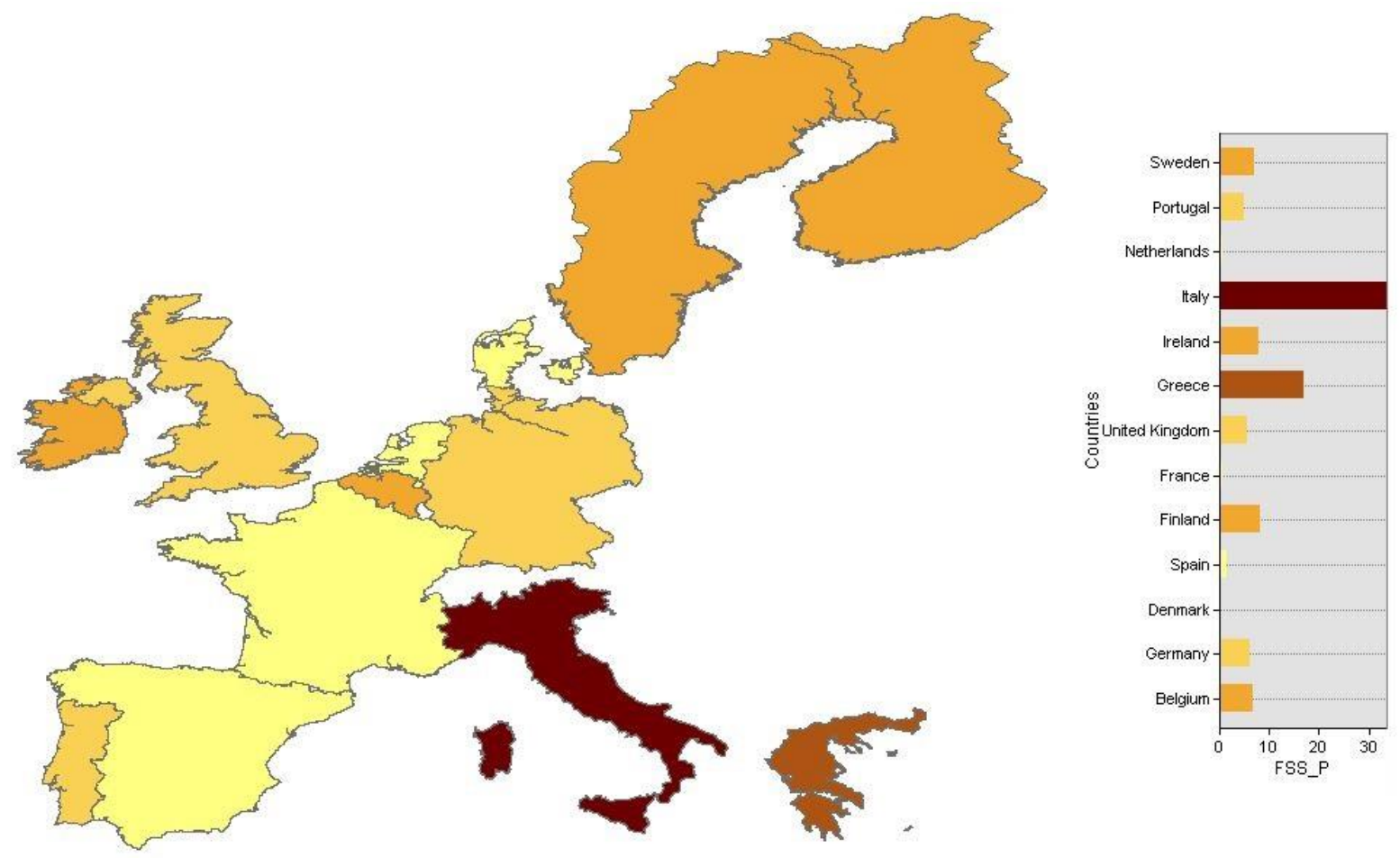

Figure 7. Detainable remarks percentage for FSS Code for EU15 countries. 

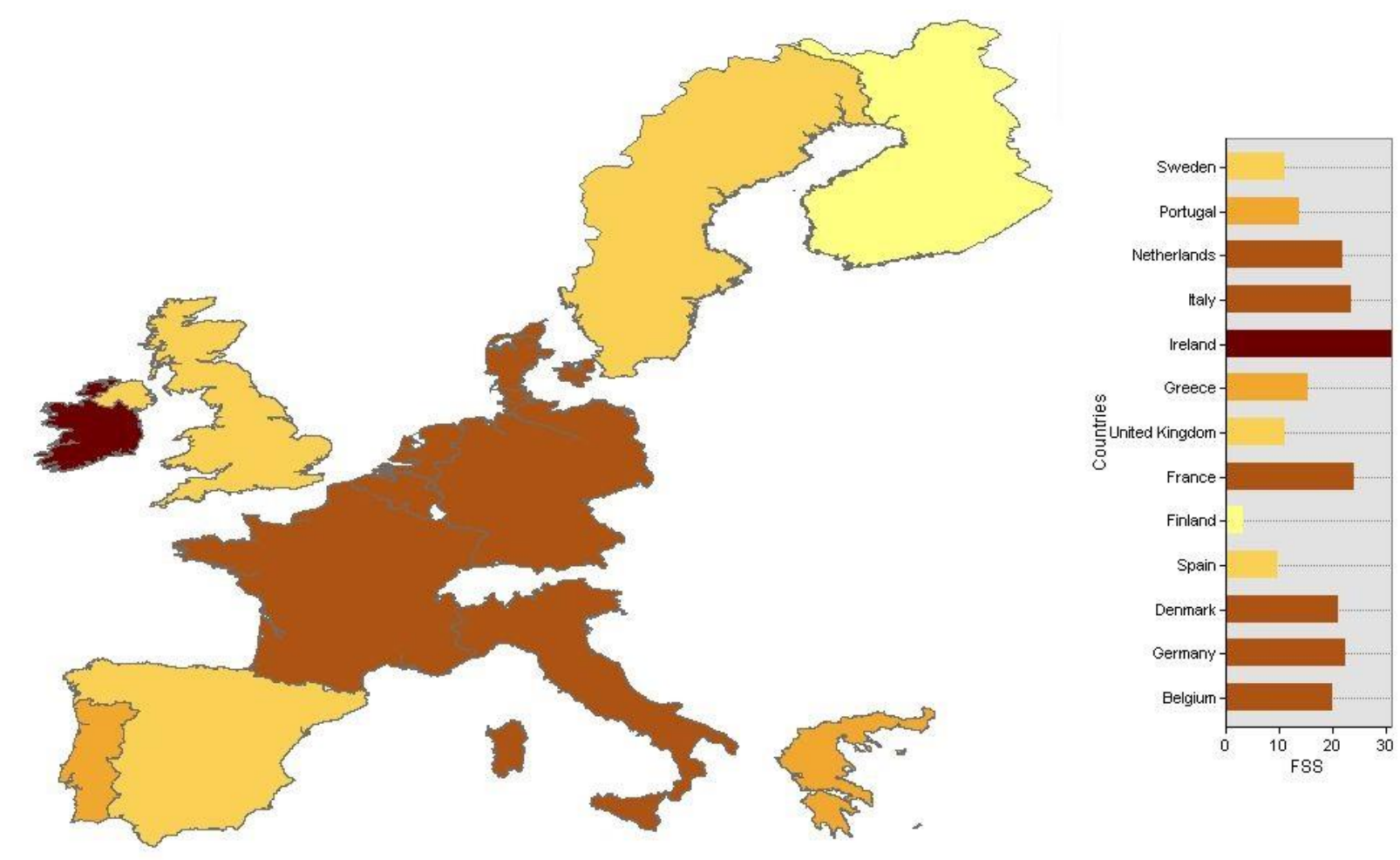

Figure 8. Weighting of FSS Code deficiencies.

The results of the AHP indicates that Ireland have utmost caution on FSS Code related deficiencies. Spain, United Kingdom and Sweden have less remarks compared the other countries and remaining countries have similar number of deficiencies on Fire Safety.
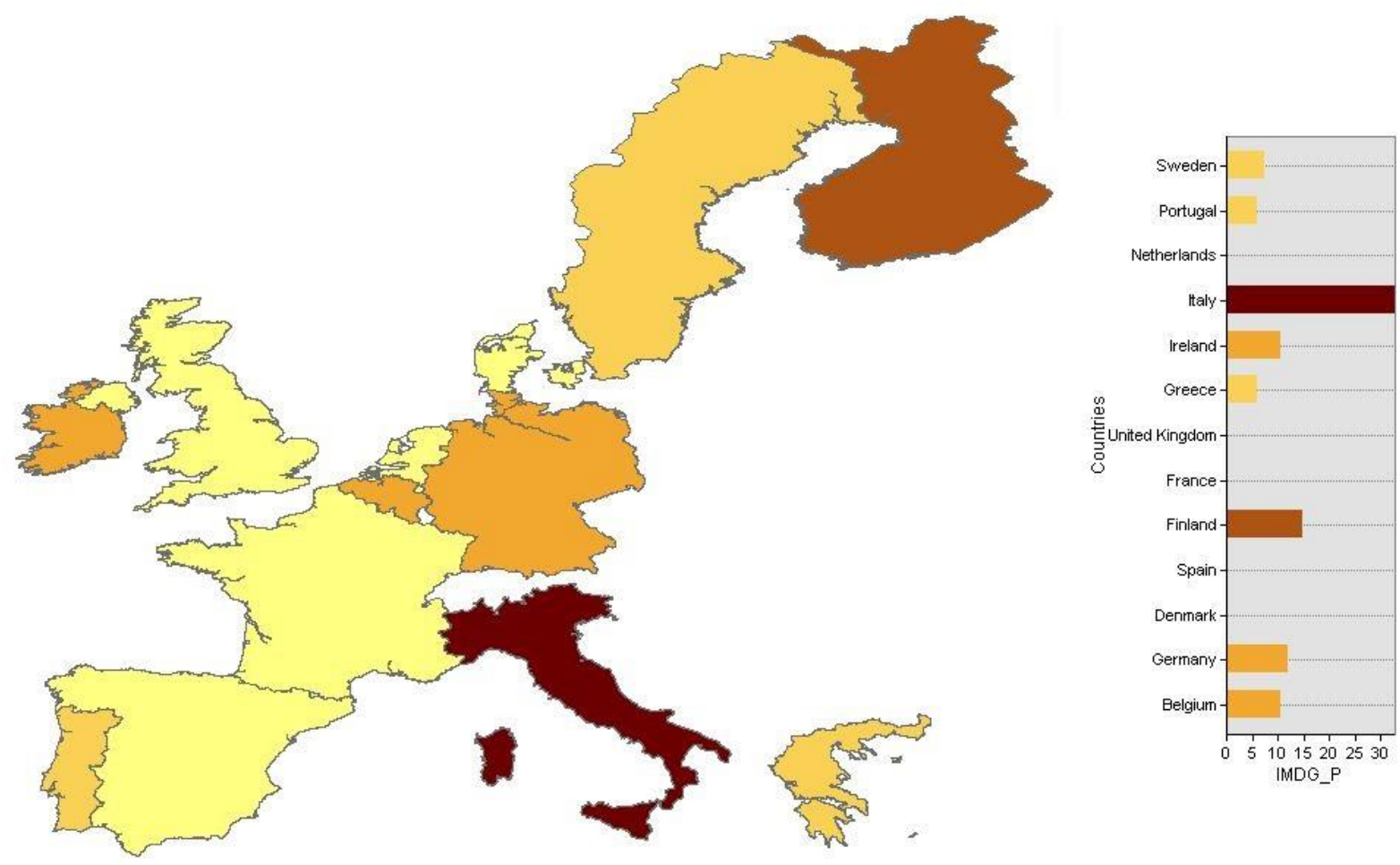
Figure 9. Detainable remarks percentage for Dangerous Goods for EU15 countries.
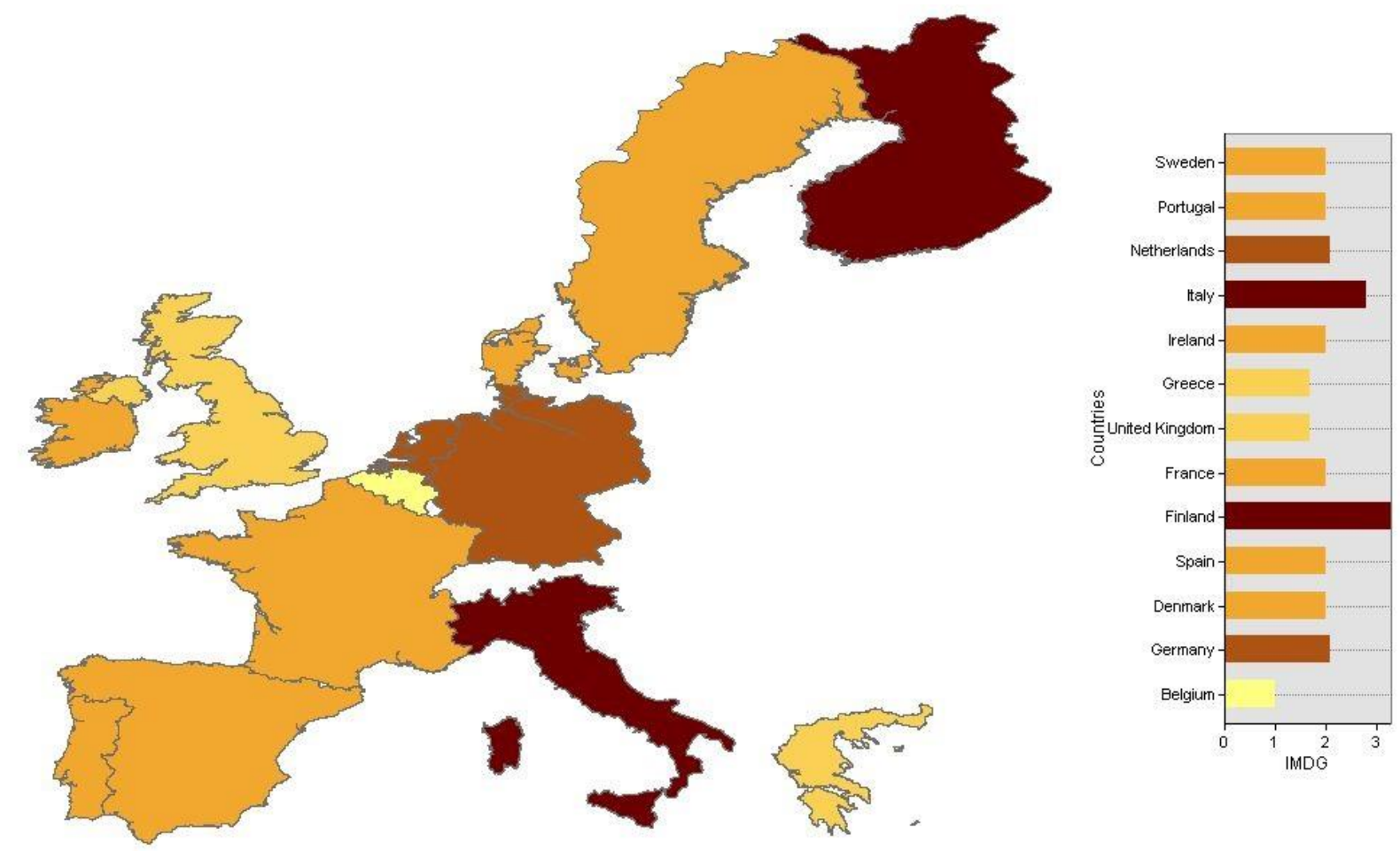

Figure 10. Weighting of Dangerous Goods deficiencies.

Italy and Finland have similar approach on Dangerous Goods and cargo related deficiencies than the other countries. Even though, the approach for Dangerous Goods is not walloping as other regulations, regarding to the detention density. Belgium have significantly low detention remarks for cargo related items compared to rest of the countries.
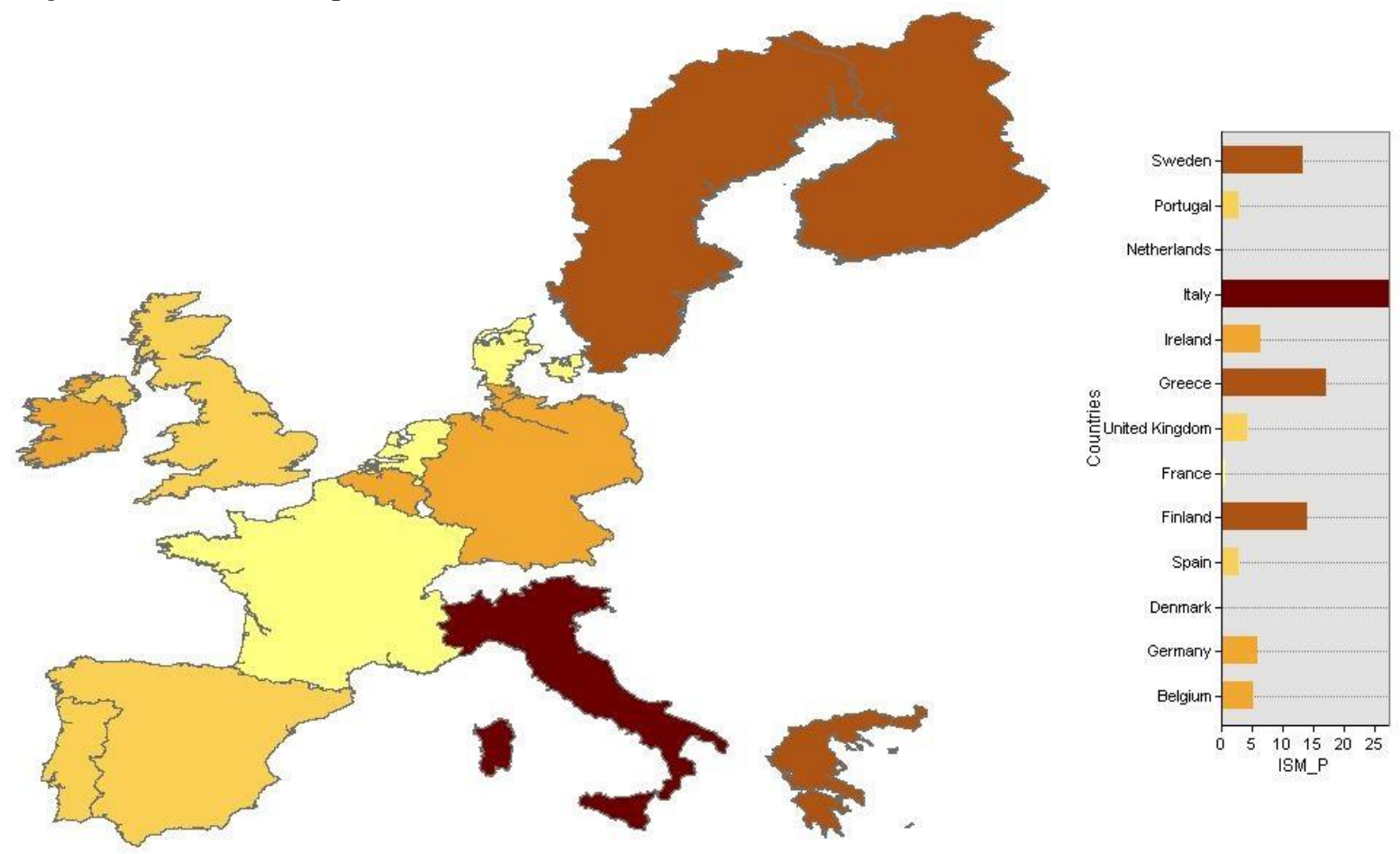
Figure 11. Detainable remarks percentage for ISM Code for EU15 countries.

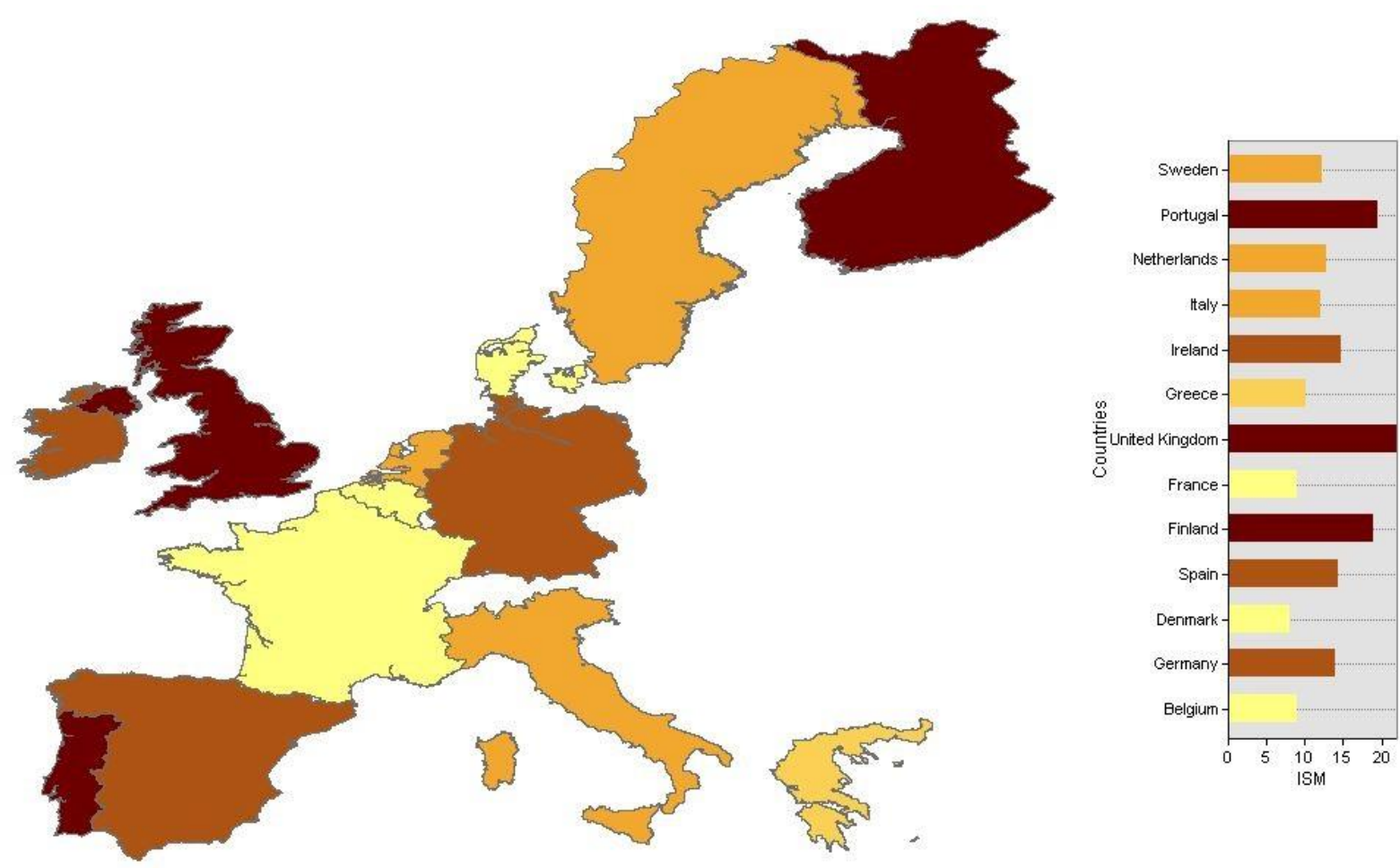

Figure 12. Weighting of ISM Code deficiencies.

The ISM Code have done a significant change in maritime industry [26]. According to spatial analysis, United Kingdom, Portugal and Finland are more likely to detain the vessel ISM caused remarks. In contrast, Belgium, Denmark and France have similar aspect on ISM Code. Besides, Ireland, Spain and Germany are close to average detention rate. 

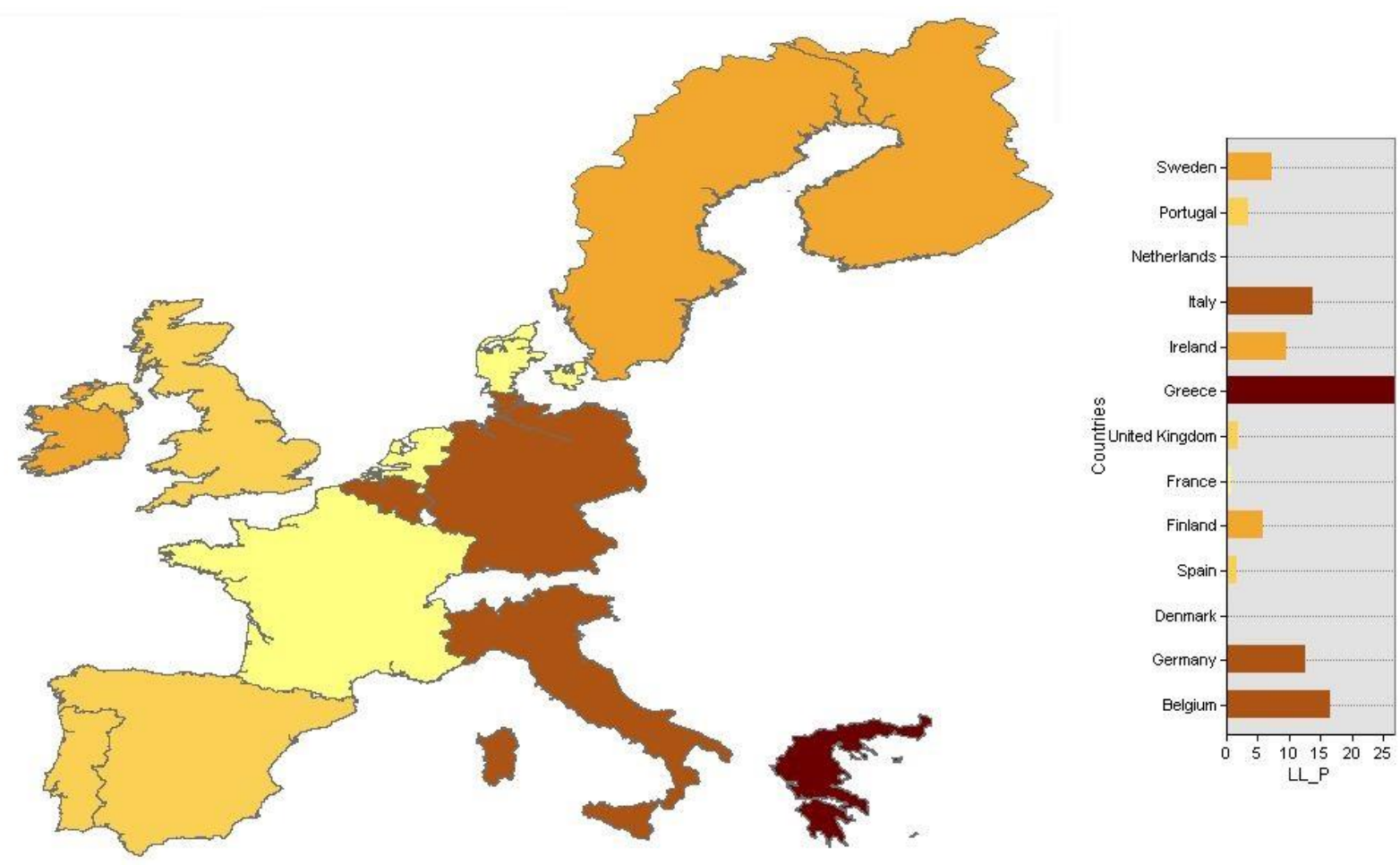

Figure 13. Detainable remarks percentage for Load Lines Protocol for EU15 countries.
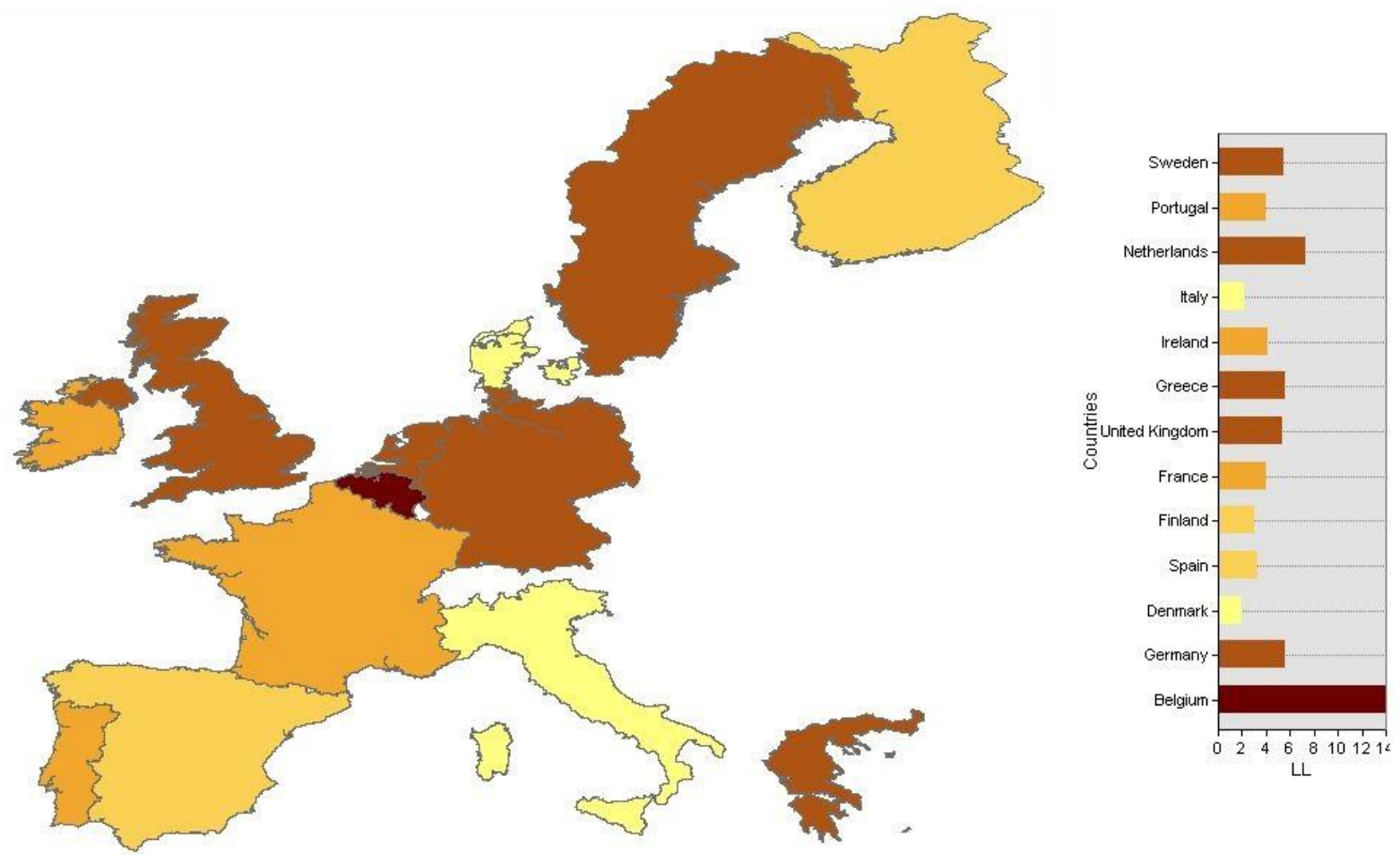

Figure 14. Weighting of Load Lines Protocol deficiencies.

Significantly, Belgium have an utmost caution for Load Lines related deficiencies among other countries. Except for Finland, remaining countries indicate similar results. 


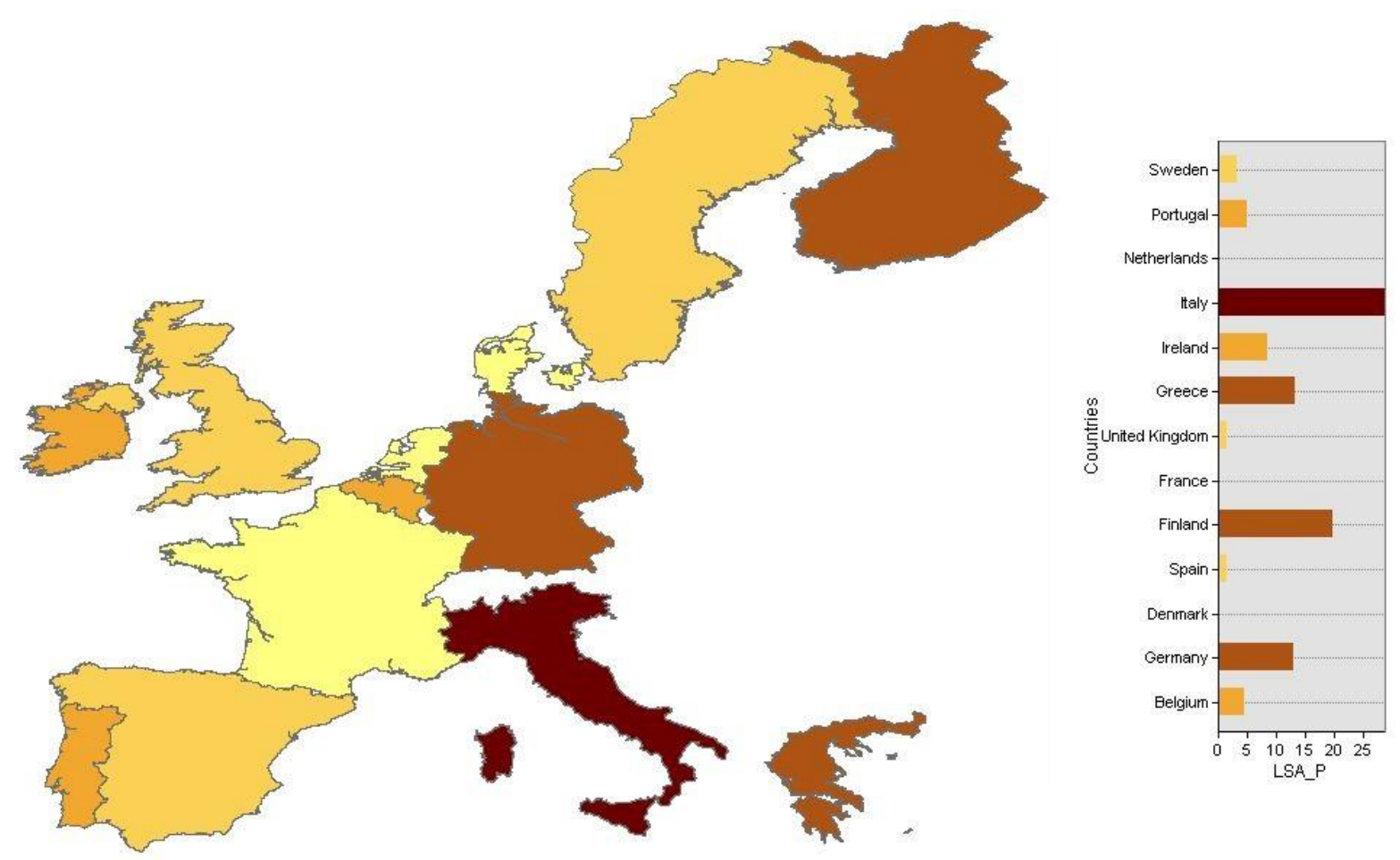

Figure 15. Detainable remarks percentage for LSA Code for EU15 countries.
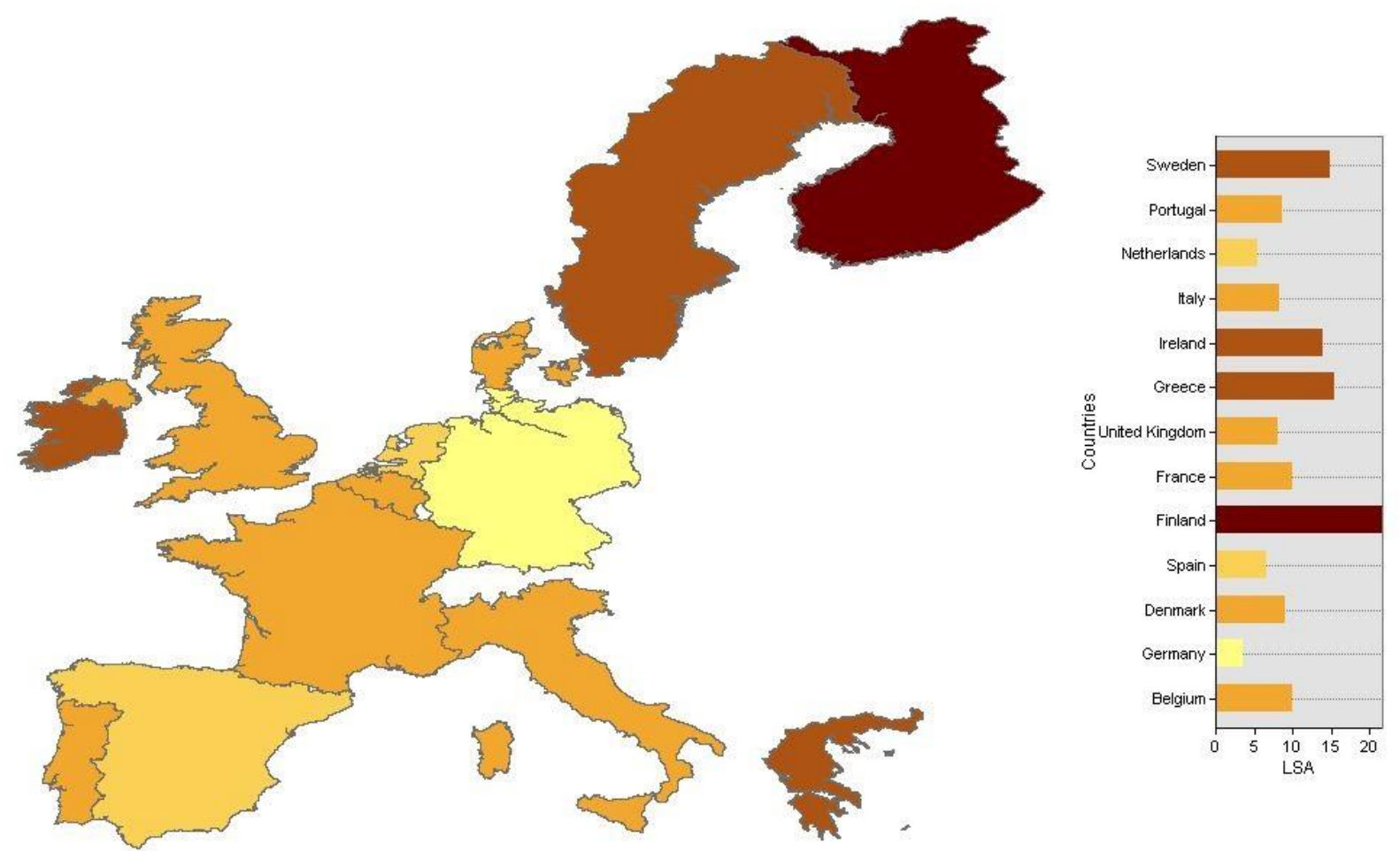

Figure 16. Weighting of LSA Code deficiencies.

LSA Code is one of the vital regulations for the maritime industry. Providing sacred human life at sea has been practicing for a thousand years. For the detention perspective, three countries to come 
into prominence as Greece, Sweden and Ireland. In contrast, Finland and Germany have significantly low - detention rates for LSA Code related deficiencies.
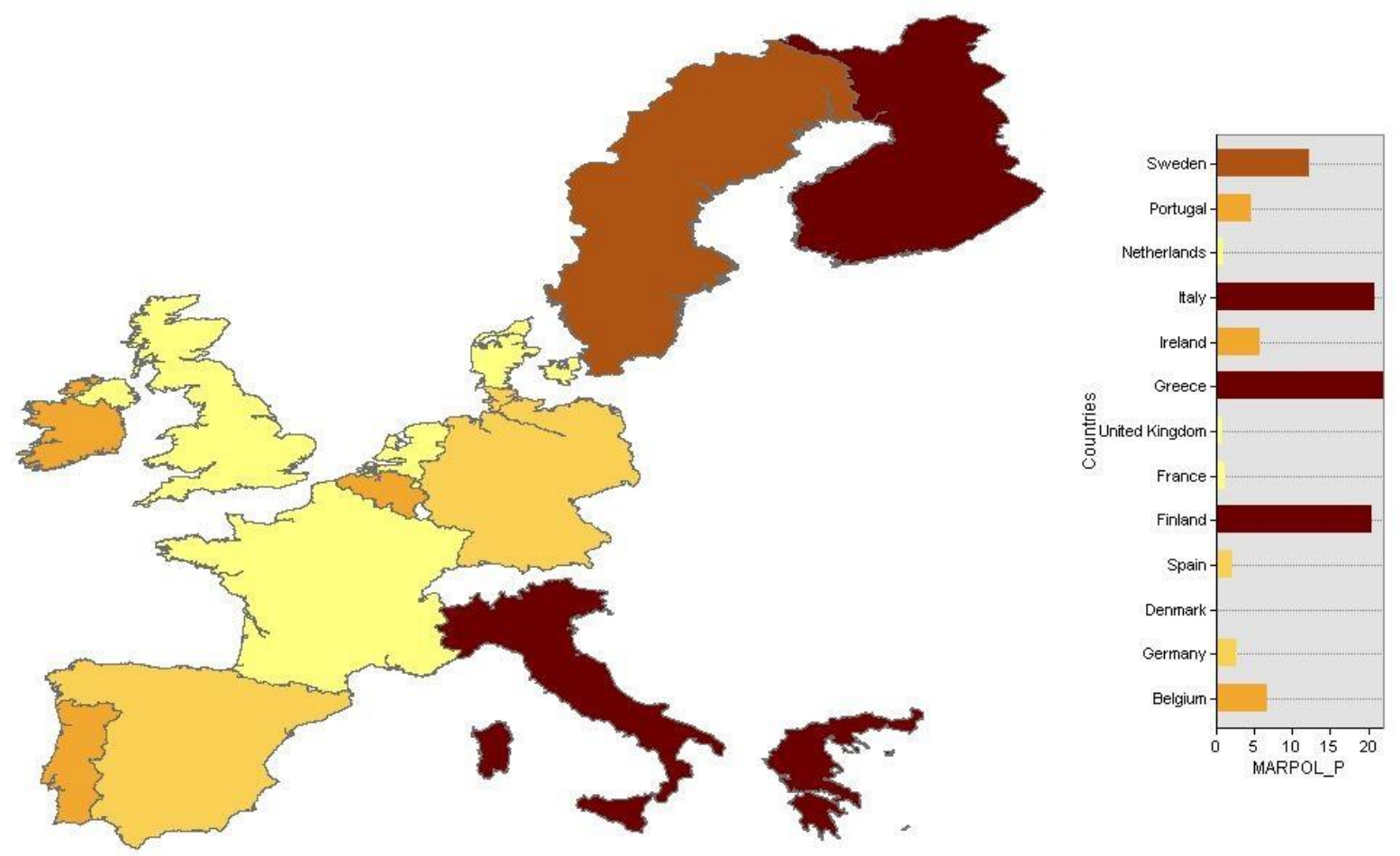

Figure 17. Detainable remarks percentage for MARPOL Convention for EU15 countries.
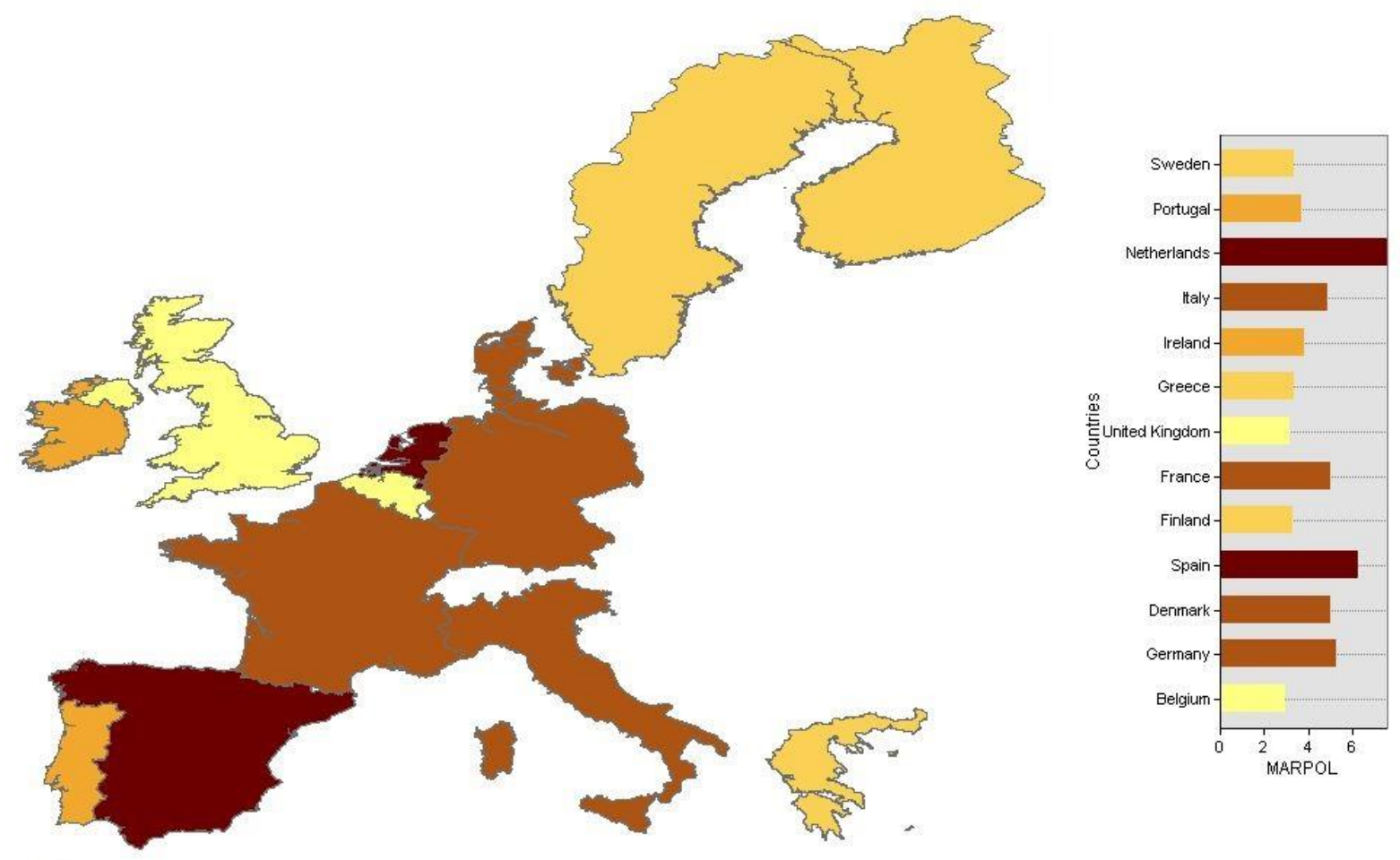

Figure 18. Weighting of MARPOL Convention deficiencies. 
MARPOL Convention is crucial to protect marine environment. After serious accidents, oil spills and incidents, six annexes of the convention aim to reduce marine pollution from ships. As spatial analysis indicates, Netherlands have ultimate awareness for marine pollution but Belgium has the minimum deficiency rate. Spain has the second highest rate for detention rate and remaining countries indicate average scores.
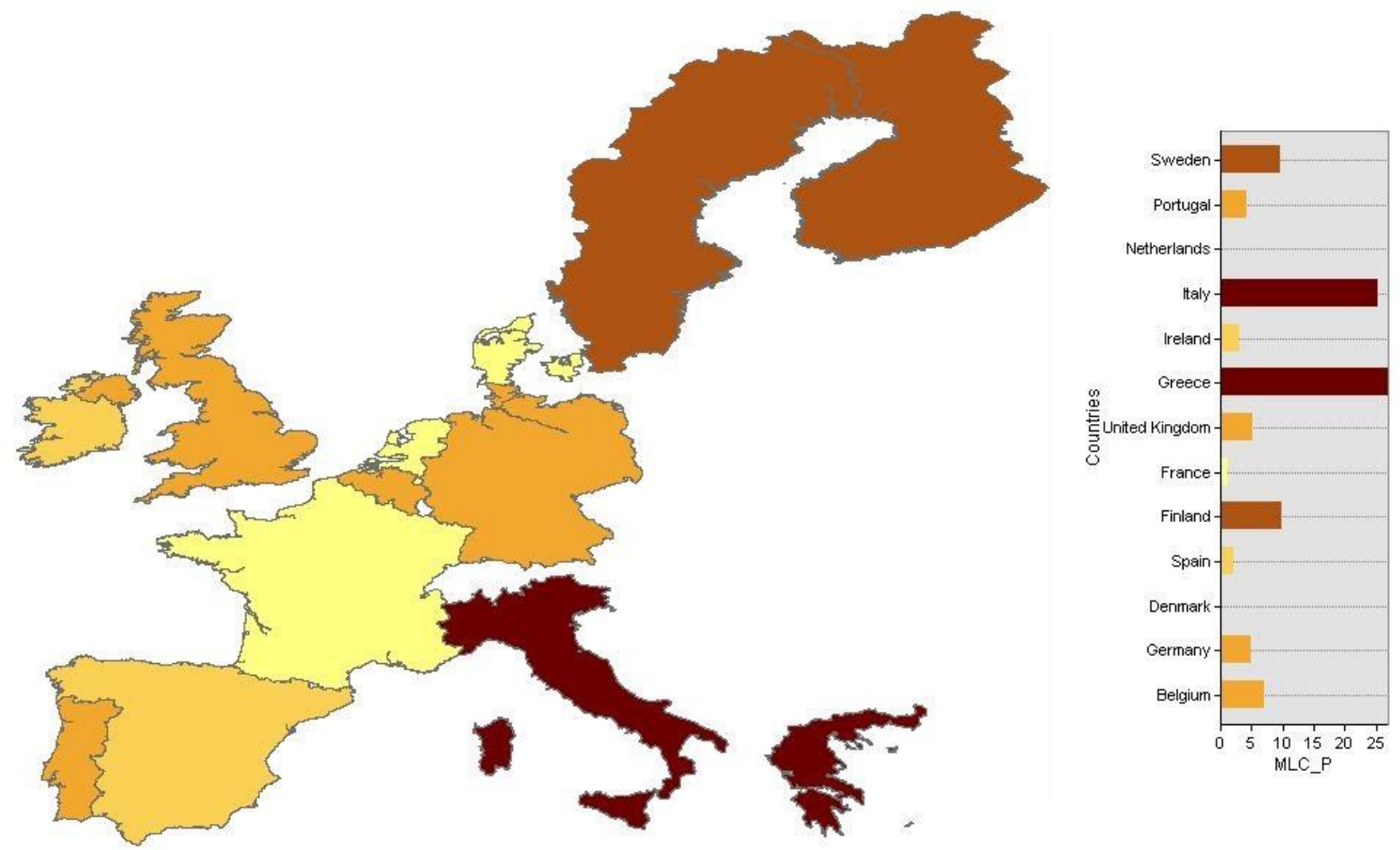

Figure 19. Detainable remarks percentage for Maritime Labor Convention for EU15 countries.
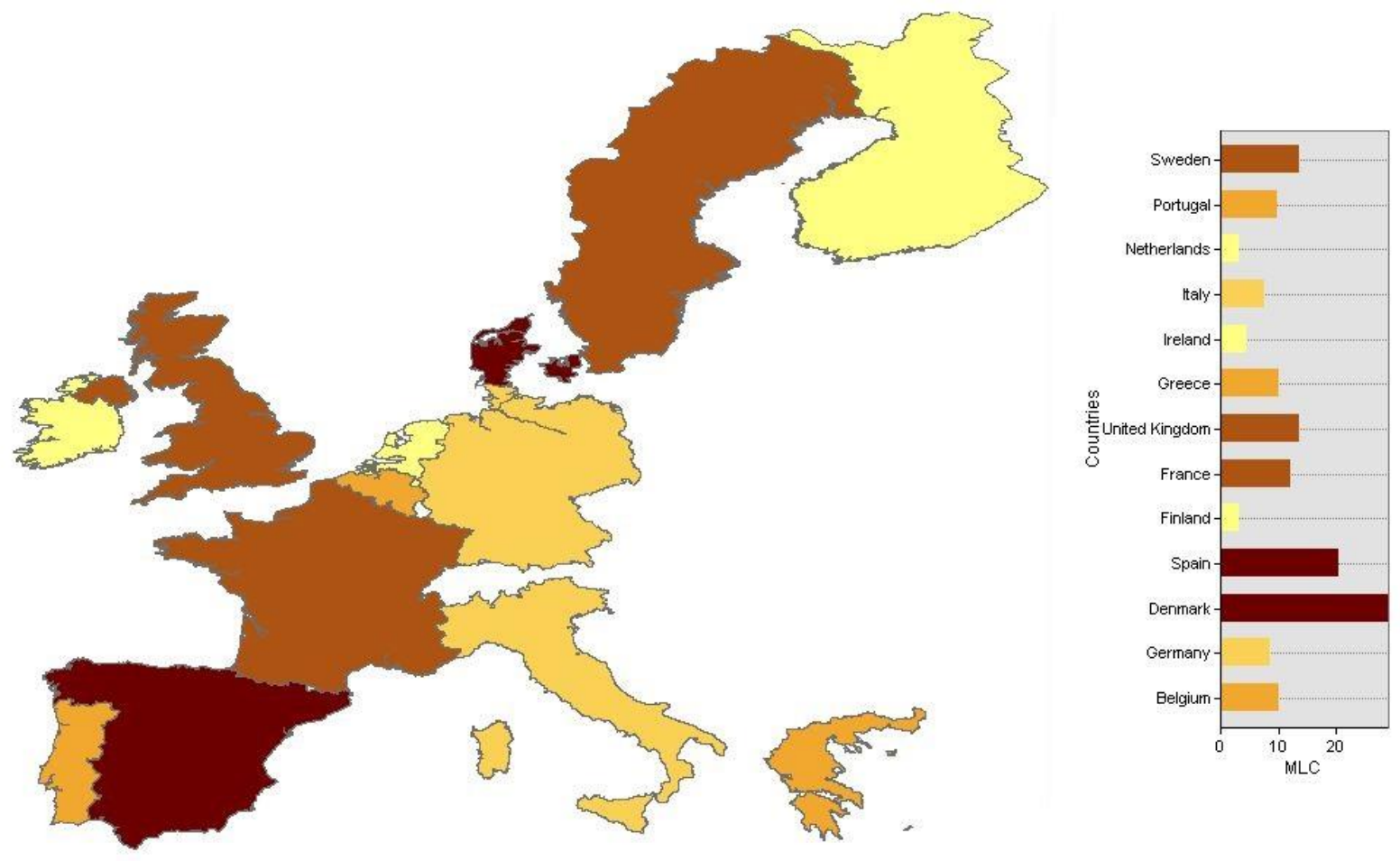
Figure 20. Weighting of Maritime Labor Convention deficiencies.

Even though the Maritime Labor Convention came into force on 20 August 2013, the ships have been inspected under ILO conventions for years. The analysis result indicates, Denmark have the highest detention rate for MLC related deficiencies. In contrast, the Netherlands, Ireland and Finland have similar minimum deficiency rate on detentions.

All in all, the spatial analysis presents us that SOLAS Convention indeed is an essential regulation that causes detention. Besides, further analysis indicates, remaining countries have different approaches and characteristics on regulations. Belgium Port State Control Officers apparently considers Load Line related deficiencies more than the rest of the states. The FSS Code is an important detention deficiency, even more than SOLAS Convention. Italy and Finland have the same approach on Dangerous Goods related deficiencies and the United Kingdom detains the vessels because of ISM Code deficiencies. LSA Code deficiencies are essential for Greece, Sweden, and Ireland to detain the ships. Netherlands have utmost importance on MARPOL Convention and the majority inspection records indicates, the root cause of the detention is a violation of Air Pollution Regulations. Denmark detention deficiencies shows, Maritime Labor Convention (formerly ILO) deficiencies are more likely to bring a detention for ships.

At this juncture, the spatial analysis points out which member state has more attention on which international regulation by detaining the visiting ship under the New Inspection Regime (NIR). This study also emphasizes, the Port State Control Officers have various backgrounds and individuals have a different aspect to detain the ships with deficiencies under professional judgement.

\section{Conclusions}

After the serious incidents, Port State Control became a volunteer to almost mandatory action to inspect ships to protect the national environment of coastal states. Inspecting a ship is not a simple target to achieve because of socio-economical varieties, and especially because of the human factor. However, the existing literature and the recent accidents clearly signify that the Port State Control has accomplished a drastic difference in overall safety and environmental pollution prevention.

The analysis on Port State Control inspection results indicate that sometimes even Port State Control is not strong enough to fight against substandard vessels [27]. Individual inspections for Port State Control indicates remarkable results; however, point of view may mislead the results since there are 207 coastal countries. Port States are in a formation of Memorandum of Understandings. Currently, there are 10 MOUs in the world as, Paris Memorandum Secretariat, Tokyo MoU, Vina del Mar Agreement, Mediterranean MoU, Indian Ocean MoU, Riyadh MoU, Black Sea MoU, Caribbean MoU and Abuja MoU. Exceptionally, United States are not under possession of any MoU, because United States Coast Guard is either part of the armed forces and inspects ships under international maritime standards. Paris MOU is a pioneer organization for several aspects such as vessel banning, information sharing and ship inspection strategy. The official website and inspection search module are open public same as other MOU's, the inspection procedures and guidelines are posted as well. 
The detailed spatial analysis among the Paris MOU member and EU15 countries indicates each country contains a different point of view to execute a judgement of detention. Besides, a further study may analyze the Port State Control remarks taking account into the sub-category of the deficiencies.

The critical importance of AHP for this analysis to cover zero detention remarks for some countries. For an instance, there is no detention for Load Line Convention in Denmark. This is not mean that any vessel has a Port State Control in Denmark with major Load Line deficiency will not subject detention and each convention has own value even though there is no detention. This analysis aims to demonstrate country profile and characteristics for overall ship detentions. In this way, ship owners/ managers and policy makers may evaluate their self-awareness on Port State Controls and their country characteristics on detainable deficiencies.

\section{References}

1. Keselj, T. Port State Jurisdiction in Respect of Pollution from Ships: The 1982 United Nations Convention on the Law of the Sea and the Memoranda of Understanding. Ocean Dev. Int. Law 1999, 30, 127-160.

2. Hare, J. Port State Control: Strong Medicine to Cure a Sick Industry. Ga. J. Int. Comp. Law 1997, 26 (3), 571-594.

3. Cariou, P.; Mejia, M.Q.; Wolff, F.-C. On the effectiveness of port state control inspections. Transp. Res. Part E Logist. Transp. Rev. 2008, 44, 491-503.

4. Why does the EU Need the European Maritime Safety Agency? Available online: http://www.emsa.europa.eu/emsa-homepage/80-about/60-why-does-the-eu-need-the-european-maritime -safety-agency.html (accessed on May 14, 2019).

5. Rodríguez, E.; Piniella, F. The New Inspection Regime of the Paris Mou on Port State Control: Improvement of the System. 2012, 7.

6. Cariou, P.; Wolff, F.-C. Identifying substandard vessels through Port State Control inspections: A new methodology for Concentrated Inspection Campaigns. Mar. Policy 2015, 60, 27-39.

7. Masroeri, A.A.; Artana, K.B.; Pitana, T.; Putranta, D.D. A Review on Some Research Issues on AIS to Improve the Ship Safety Operation at Sea. J. Marit. Res. 2012, 2, 11-23.

8. Knapp, S.; Franses, P.H. Effect and Improvement Areas for Port State Control Inspections to Decrease the Probability of Casualty. 48.

9. Hänninen, M.; Kujala, P. Bayesian network modeling of Port State Control inspection findings and ship accident involvement. Expert Syst. Appl. 2014, 41, 1632-1646.

10. Cariou, P.; Mejia, M.Q.; Wolff, F.-C. An econometric analysis of deficiencies noted in port state control inspections. Marit. Policy Manag. 2007, 34, 243-258.

11. Cariou, P.; Wolff, F.-C. Do Port State Control Inspections Influence Flag- and Class-hopping Phenomena in Shipping? J. Transp. Econ. Policy 2011, 45, 155-177.

12. Knapp, S.; Franses, P.H. Econometric analysis on the effect of port state control inspections on the probability of casualty. Mar. Policy 2007, 31, 550-563.

13. Knapp, S.; Bijwaard, G.; Heij, C. Estimated incident cost savings in shipping due to inspections. Accid. Anal. Prev. 2011, 43, 1532-1539.

14. Liou, S.; Liu, C.-P.; Chang, C.-C.; Yen, D.C. Restructuring Taiwan's port state control inspection authority. Gov. Inf. Q. 2011, 28, 36-46.

15. Akyuz, E.; Karahalios, H.; Celik, M. Assessment of the maritime labour convention compliance using balanced scorecard and analytic hierarchy process approach. Marit. Policy Manag. 2015, 42, 145-162.

16. Ravira, F.J.; Piniella, F. Evaluating the impact of PSC inspectors' professional profile: a case study of the Spanish Maritime Administration. WMU J. Marit. Aff. 2016, 15, 221-236.

17. Graziano, A.; Cariou, P.; Wolff, F.-C.; Mejia, M.Q.; Schröder-Hinrichs, J.-U. Port state control inspections in the European Union: Do inspector's number and background matter? Mar. Policy 2018, 88, $230-241$.

18. Kiehne, G. Investigation, Detention and Release of Ships under the Paris Memorandum of Understanding on Port State Control: A View from Practice. Int. J. Mar. Coast. Law 1996, 11.

19. Saaty, T.L.; Vargas, L.G. Models, methods, concepts \& applications of the analytic hierarchy process; International series in operations research \& management science; 2. ed.; Springer: New York, 2012; ISBN 978-1-4614-3596-9. 
20. Kandakoglu, A.; Celik, M.; Akgun, I. A multi-methodological approach for shipping registry selection in maritime transportation industry. Math. Comput. Model. 2009, 49, 586-597.

21. Jung, H.; Kim, J.; Shin, K. Importance Analysis of Decision-Making Factors for Selecting International Freight Transportation Mode. Asian J. Shipp. Logist. 2019, 35, 55-62.

22. Giamalaki, M.; Tsoutsos, T. Sustainable siting of solar power installations in Mediterranean using a GIS/AHP approach. Renew. Energy 2019, 141, 64-75.

23. Saaty, T.L. Decision making with the analytic hierarchy process. Int. J. Serv. Sci. 2008, 1, 83.

24. History of fire protection requirements Available online: http://www.imo.org/en/OurWork/Safety/FireProtection/Pages/History-of-fire-protection-requirements.as px (accessed on May 5, 2019).

25. ISM

Code Available

online: http://www.imo.org/en/OurWork/HumanElement/SafetyManagement/Pages/ISMCode.aspx (accessed on May 5, 2019).

26. Bhattacharya, S. The effectiveness of the ISM Code: A qualitative enquiry. Mar. Policy 2012, 36, 528-535.

27. Payoyo, P.B. Implementation of international conventions through port state control: an assessment. Mar. Policy 1994, 18, 379-392. 